\title{
The Alternative InVESTMENT MARKET: Helping SMall ENTERPRises Grow PUbliC
}

\author{
JONATHAN R. HORNOK*
}

ABSTRACT

The Alternative Investment Market ("AIM") of the London Stock Exchange is a twenty-year experiment in light securities regulation for small companies. The empirical literature shows that the AIM underperforms premier exchanges; however, this literature should not be taken as evidence that the AIM experiment is a failure, rather that the AIM serves a unique niche. In contrast to companies listing on premier exchange, those listing on the AIM do not undergo significant changes in ownership, control, and leverage after an initial public offering ("IPO"). Instead, these changes occur over time, if the company grows. This Article argues, based on the empirical literature, that the AIM fills a niche for companies and investors that fits between a premier exchange listing, which is difficult to attain, and remaining completely private, even aided by an issuer sponsored secondary market. From this middle ground, companies may successfully use the AIM as an on-ramp to a listing on the Main Market of the London Stock Exchange; however, less than one percent of companies are able to make this transition. Even if companies do not have the Main Market in their sights, the AIM serves as a structured liquidity market for existing investors. The Appendices to this Article present a detailed overview of the empirical findings from each of the reviewed studies.

\section{INTRODUCTION}

The Alternative Investment Market ("AIM") of the London Stock Exchange is an experiment in light securities regulation for small and emerging enterprises. While the AIM appears in securities literature, only a few studies report empirical analysis of the market. With so few studies completed, there is no consensus on the success, or failure, of the market and the light regulation model it represents. This Article adds to the literature by digging deep into each empirical study and distilling the statistical landscape. Further, this Article argues that while the AIM significantly underperforms premier exchanges with heavier regulation, it bridges the gap between a premier exchange listing and remaining

* Jonathan R. Hornok. Judicial Law Clerk to Justice Jill N. Parrish, Supreme Court of the State of Utah. The views expressed here are my own; they do not reflect the views of Justice Parrish or the Utah Supreme Court. I would like to thank Jeff Schwartz for his thoughtful comments. 
completely private. From this middle ground, the AIM plays two roles: First, companies can use the AIM as an on-ramp to the Main Market of the London Stock Exchange by growing into the heavy burden of regulation over time. Second, companies can use the AIM to provide a structured liquidity market for existing shareholders, even without a Main Market listing in sight.

The last decade has seen a significant reduction in the number of

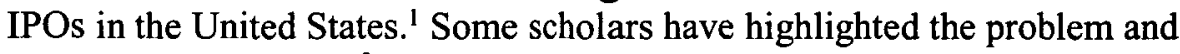
are calling for change. ${ }^{2}$ For those scholars looking for a solution, the AIM is an exciting development for the return of IPOs-small IPOs in particular. $^{3}$ Not everyone agrees. In 2007, Roel Campos, an SEC commissioner at the time, picked a fight with the London Stock Exchange by describing the AIM "as a casino on which 30 per cent of listings were 'gone within a year."' The London Stock Exchange contended that Mr. Campos's characterization was "entirely wrong" and was motivated by "jealousy over A[IM]'s success in attracting U.S. listings."

In the U.S., private companies finance growth on their way to an IPO on a premier exchange either through debt or through the private sale of equity. ${ }^{6}$ Once equity is sold, however, investors have few options to trade their shares in a secondary market. A private company may sponsor a private market for their shares using a service such as SharesPost or SecondMarket, but these are not public exchanges and do not provide the same protections and benefits to individual shareholders. ${ }^{7}$ The traditionalists in the U.S. securities market are satisfied with keeping smallcompany financing strictly private, but regulators should consider the AIM

\footnotetext{
1 Jeff Schwartz, The Twilight of Equity Liquidity, 34 CARDOZO L. REV. 531, 544 (2012). However, recently higher numbers of IPOs may indicate somewhat of a rebound. Olivia Oran et al., Global IPOs Rise on Stock Market Rebound, Private Equity Exits, REUTERS (Mar. 28, 2013, 12:59 PM), http://www.reuters.com/article/2013/03/28/us-ipo-roundup-1 stquarteridUSBRE92R0OL20130328.

${ }^{2}$ Schwartz, supra note 1 , at 533-36.

${ }^{3}$ See id. at 547; Jose Miguel Mendoza, Securities Regulation in Low-tier Listing Venues: The Rise of the Alternative Investment Market, 13 FORDHAM J. CORP. \& FIN. L. 257, 261-63 (2008), available at http://law.fordham.edu/assets/JCFL/Mendoza_JCI3_FJCFL_Vol.XIII.2.pdf. ${ }^{4}$ Norma Cohen et al., Top SEC Official Calls AIM a 'Casino', FIN. TIMES (Mar. 9, 2007, 2 AM), http://www.ft.com/cms/s/0/fa3488b8-cde4-11db-839d000b5df10621.html\#axzz3IO8LXwd0.

${ }^{5}$ Id.

${ }^{6}$ Schwartz, supra note 1 , at 550-51.

${ }^{7}$ See About SharesPost, SHARESPOST, http://sharespost.com/about-us/aboutsharespost/; Secondary Transactions, SECONDMARKET, https://www.secondmarket.com/secondary.
} 
as an example of the benefits of lighter regulation in a public, structured exchange.

This Article proceeds as follows: Part II develops a background by introducing the AIM and some of its distinguishing features. Part III introduces the empirical literature and this Article's research approach. Part IV reviews the empirical data showing the underperformance of the AIM as compared to premier exchanges. Part V argues that the AIM bridges the gap between premier exchanges and remaining a private company. Part VI concludes and identifies areas for further study and analysis. Appendix 1 contains a bibliography of the relevant empirical literature. Appendix 2 contains an extensive chart detailing the empirical findings from all of the reviewed empirical literature.

\section{THE ALTERNATIVE INVESTMENT MARKET}

The London Stock Exchange founded the AIM in $1995 .^{8}$ Springing from the deregulation of the Thatcher years, the AIM was an experiment in light securities regulation. ${ }^{9}$ Almost twenty years later, the AIM has survived through the dot com bubble of 2000 and the global economic downturn of $2008 .^{10}$

The distinguishing feature of the AIM is its model of regulation. Unlike the premier exchanges such as the NASDAQ, the New York Stock Exchange, and the Main Market of the London Stock Exchange, which are actively regulated by government authorities, nominated advisors ("nomads") administer the exchange's principles-based regulations. ${ }^{11}$ The exchange, not the government regulator, promulgates a number of principles for companies to follow and nomads act as an inside regulator doing the due diligence necessary to ensure that a company is suitable for initial and continued listing on the AIM. ${ }^{12}$ The exchange seeks to strike a balance between the interests of investors and the regulatory burden on the small companies that make up the AIM. ${ }^{13}$ For example, companies are not required to comply with corporate governance and internal control standards that burden similar companies in the U.S. under Sarbanes-

\footnotetext{
${ }^{8}$ Marcus Stuttard, Foreword to A GuIDE To AIM 3, 3 (Nigel Page ed., 2010).

${ }^{9}$ See id.; Margaret Thatcher: No Ordinary Politician, ECONOMIST, April 13, 2013, at 26, available at http://www.economist.com/news/briefing/21576081-margaretthatcher-britains-prime-minister-1979-1990-died-april-8th-age (describing the trend of deregulation overseen by Margaret Thatcher in the 1980s).

${ }^{10}$ See London Stock Exchange, AIM-The Most Successful Growth Market, in A GUIDE TO AIM 4, 4 (Nigel Page ed., 2010) [hereinafter LSE, Growth Market].

${ }^{11}$ Id. at 5-6; London Stock Exchange, AIM Advisers, in A Guide to AIM 10, 10 (Nigel Page ed., 2010) [hereinafter LSE, AIM Advisers].

${ }^{12}$ LSE, AIM Advisers, supra note 11.

${ }^{13}$ See LSE, Growth Market, supra note 10, at 5-6.
} 
Oxley. ${ }^{14}$ This lighter regulation and lower listing costs are a primary selling point for the AIM. ${ }^{15}$ For companies going and staying public on the AIM the cost is significantly less than on the NASDAQ. ${ }^{16}$ Over sixteen hundred companies have raised over $\$ 45$ billion in capital through IPOs on the AIM. ${ }^{17}$

In terms of the number of new listings from 2000 to 2008, the AIM outperformed the NASDAQ, Main Market, and the OTC Bulletin Board, which was once a competitor operated by the Financial Industry Regulatory Authority ("FINRA"), now all but shuttered. ${ }^{\text {i8 }}$ For example, in 2005 there were 311 new listings on the AIM to only 21 on the Main Market, 132 on the NASDAQ, and 75 on the OTC Bulletin Boards. ${ }^{19}$ However, the total capital raised on the AIM was much smaller than the Main Market and the NASDAQ until 2004 and 2005, after which the AIM exceeded both premier markets in at least one year. ${ }^{20}$ In 2005 , companies raised over $\$ 9.3$ billion on the AIM as compared to only $\$ 8.7$ billion on the Main Market. ${ }^{21}$ The next year, companies raised $\$ 14.2$ billion on the AIM as compared to $\$ 12.8$ billion on the NASDAQ. ${ }^{22} \mathrm{~A}$ comparable amount of total capital raised spread across more listings means that AIM listings are generally smaller than those on premier exchanges, but the volume makes up for the smaller size.

\section{THE EMPIRICAL LITERATURE}

The empirical literature provides a systematic analysis of the AIM. However, each author brings differing perspective and goals to his or her research; they set out to answer different questions using different

\footnotetext{
${ }^{14}$ See Mendoza, supra note 3, at 269-72 \& 296-97.

${ }^{15}$ See LSE, Growth Market, supra note 10, at 5-6; FAEGRE \& BENSON LLP \& BAKER TILLEY, TAKING AIM: ANNUAL SURVEY 201029 (2010).

${ }^{16}$ Mendoza, supra note 3, at 308-09.

${ }^{17}$ LSE, Growth Market, supra note 10; Joseph Gerakos et al., Post-listing Performance and Private Sector Regulation: The Experience of London's Alternative Investment Market, 56 J. ACCT. \& ECON. 189, 195 tbl.1 (2013) [hereinafter Gerakos et al., Post-listing Performance].

${ }^{18}$ Gerakos et al., Post-listing Performance, supra note 17; About OTCQB, DEWMAR INT'L, http://www.dewmarinternational.com/about-otcqb/ (last visited Nov. 7, 2014) ("The OTCQB marketplace has effectively replaced the FINRA operated OTC Bulletin Board (OTCBB) as the primary market for SEC and bank reporting securities that trade off the exchanges."); Overview and History of the $O T C B B$, OTC BULLETIN BOARD, https://www.otcbb.com/aboutOTCBB/overview.stm (last visited Nov. 7, 2014). ${ }^{19}$ Gerakos et al., Post-listing Performance, supra note 17.

${ }^{20} \mathrm{Id}$.

${ }^{21} \mathrm{Id}$.

${ }^{22} I d$.
} 
methodologies and data sources. While any one study can be helpful to answer a few narrowly drawn questions, a single study cannot fully evaluate the AIM. Evaluated as a whole, these studies provide a more complete picture of how the AIM performs well and where it fails.

The interaction between studies is important to evaluate the weight of any empirical finding. In some cases, studies buttress one another, finding the same results through different methodology. In other cases, studies undermine one another. This Part first introduces the empirical literature reviewed by this Article. Second, this Part discusses the synthesis process used to evaluate the literature in gross and to create the summary chart contained in Appendix 2.

\section{A. Summary of Reviewed Papers}

There are only a few studies that complete empirical analysis on the AIM. These studies conduct a variety of statistical analyses, including comparing the AIM to private companies, comparing the AIM to premier exchanges, identifying indicators of success on the AIM, and charting disclosure trends as AIM companies grow. The following is a brief introduction to each of the eleven empirical studies reviewed in this Article. $^{23}$

In section four of The LSE's AIM Market: Effect of Returns and Trading of Canadian Stocks, John Board and Stephen Wells evaluate the stock performance of companies that switch between the AIM and the Main Market in an effort to compare stock performance on the two markets. ${ }^{24}$ The study excludes small companies that switched multiple times and those that switched while making fundamental changes to the nature of the company. ${ }^{25}$

In Entrepreneurial Dimensions of the Growth of Small Companies, Alessandra Colombelli evaluates six years of pre- and post-IPO performance of 665 companies that went public on the AIM between 1995 and 2006 and correlates performance with firm characteristics at the time of the IPO ${ }^{26}$ The focus of this study is on operating performance of companies as described in financial statements. ${ }^{27}$ This measure, as opposed to stock-

\footnotetext{
${ }^{23}$ The studies are alphabetized by the first author's last name. See infra Appendix 1 for a bibliographic chart of these studies.

${ }^{24}$ John Board \& Stephen Wells, The LSE's AIM Market: Effect on Returns and Trading of Canadian Stocks, in 5 CANADA STEPS UP 173, 212-13 (Task Force to Modernize Sec. Legislation in Can. ed., 2006).

${ }^{25} \mathrm{Id}$. at 214.

${ }^{26}$ Alessandra Colombelli, Entrepreneurial Dimensions of the Growth of Small Companies 10, 12-13 (Università Degli Studi Di Torino, Dipartimento di Economia e Statistica "Cognetti de Martiis", Working Paper No. 2/2009, 2009). ${ }^{27} I d$.
} 
based performance, tracks how AIM companies perform regardless of their reputation in the market.

In Is AIM a Casino? A Study of the Survival of New Listings on the UK Alternative Investment Market (AIM), Susanne Espenlaub, Arif Khurshed, and Abdul Mohamed evaluate the short-term failure of 641 companies with an IPO on the AIM between 2000 and 2004 and correlate the long-term survival rate of 316 companies with company characteristics. ${ }^{28}$ This study is a direct response to SEC Commissioner Roel Campos's characterization of the AIM as a casino. ${ }^{29}$

In Post-Listing Performance and Private Sector Regulation: The Experience of London's Alternative Investment Market, Joseph Gerakos, Mark Lang, and Mark Maffett compare the stock performance of companies that listed on the AIM between 1995 and 2008 with those that listed on the Main Market of the London Stock Exchange, the NASDAQ, or the OTC Bulletin Board, when it was regulated by the SEC.$^{30}$ Out of their original pool of 1,601 AIM companies and 2,406 premier exchange companies, the authors were able to match 1,241 AIM companies with a benchmark counterpart on one of the premier exchanges. ${ }^{31}$ The authors required that matched firms have a market value of listing within $\$ 25$ million and a listing date within one year. ${ }^{32}$ This study compares the exchanges using several performance measures and identifies several AIM firm and nomad characteristics that are associated with better or worse performance. ${ }^{33}$ This study is comprehensive and provides an expansive comparison of the AIM with other exchanges. Finally, this study appears to be the published version of an earlier working paper by the same authors titled Listing Choices and Self-Regulation: The Experience of the AIM. ${ }^{34}$

In Directors' Dealing and Post-IPO Performance, Hafiz Hoque and Meziane Lasfer combine director trading information with IPO and

\footnotetext{
${ }^{28}$ Susanne Espenlaub et al., Is AIM a Casino? A Study of the Survival of New Listings on the UK Alternative Investment Market (AIM) 13-14 (unpublished manuscript) (on file with the Manchester Business School Manchester Accounting $\&$ Finance Group).

${ }^{29}$ See id. at 4.

${ }^{30}$ See Gerakos et al., Post-listing Performance, supra note 17, at 189 \& 194.

${ }^{31}$ Id. at 195.

${ }^{32} \mathrm{Id}$.

${ }^{33}$ See id. at $189-92$.

${ }^{34}$ See Joseph Gerakos et al., Listing Choices and Self-Regulation: The Experience of the AIM 6, 8 \& 14-15 (The Univ. of Chi. Booth Sch. of Bus., Working Paper No. 11-04, 2011), [hereinafter Gerakos et al., Listing Choices] available at http://ssrn.com/abstract=1739137. This Article excludes references to the earlier working paper where the results are identical to what is found in the later version published in the Journal of Accounting and Economics. However, there are some instances where the working paper includes additional helpful information.
} 
company performance data for companies listed on one of the London Stock Exchange markets between 1999 and 2006. ${ }^{35}$ The authors categorize the companies based on their net purchase ratio-purchases less sells all over total trades-and find $190(35 \%)$ IPOs with net selling by directors and $353(65 \%)$ with net buying. ${ }^{36}$ Finally, the authors analyze the association between directors' trading activity and company performance. ${ }^{37}$

In The Operating and SharePrice Performance of Initial Public Offerings: The UK Experience, Arif Khurshed, Stefano Paleari, and Silvio Vismara compare four years of post-IPO performance for 195 companies that listed on the AIM with 216 companies that listed on the Main Market from 1995 through $1999 .{ }^{38}$ The study excludes 210 IPOs of investment trusts and other financial companies to narrow the sample to those IPOs representing traditional businesses. ${ }^{39}$ The study focuses on the operating performance as well as the change in ownership structure and leverage. ${ }^{40}$

In Corporate Governance in Alternative Investment Market (AIM) Companies, Chris Mallin and Kean Ow-Yong evaluate the voluntary corporate-governance standard compliance disclosures of 300 AIM companies listed on the AIM before June $2006 .^{41}$ The authors score each company based on disclosure of compliance with twenty-three best practices from the Quoted Companies Alliance ("QCA") Guidelines on Corporate Governance for AIM Companies, which is based on the UK's Combined Code. ${ }^{42}$ The authors also conduct extensive interviews with AIM companies, investors, nomads, and brokers. ${ }^{43}$ Chis Mallin also presented a paper in 2009, which was written with Kean Ow-Yong, covering similar findings; the paper is titled Corporate Governance in Alternative Investment Market (AIM) Companies: Determinants of Corporate Governance Disclosure. ${ }^{44}$

\footnotetext{
${ }^{35}$ Hafiz Hoque \& Meziane Lasfer, Directors' Dealing and Post-IPO Performance, EUR. J. FIN. (forthcoming) (manuscript at 5-6).

${ }^{36} I d$. at 6.

${ }^{37}$ See generally id.

${ }^{38}$ Arif Khurshed et al., The Operating and SharePrice Performance of Initial Public Offerings: The UK Experience 9 (unpublished manuscript)(on file with author).

${ }^{39}$ Id. at $9-10$.

${ }^{40}$ See id. at $20-21$.

${ }^{41}$ Chris MALLIN \& KeAN OW-Yong, INST, OF ChaRTERED ACCOUNTANTS OF SCOT., CORPORATE GOVERNANCE IN ALTERNATIVE INVESTMENT MARKET (AIM) COMPANIES 69-71 (2008).

${ }^{42}$ Id. at I.

${ }^{43}$ See id. at 16-21.

${ }^{44}$ Chris Mallin \& Kean Ow-Yong, Corporate Governance in Alternative Investment Market (AIM) Companies: Determinants of Corporate Governance Disclosure 1 (Jan. 12, 2009) (unpublished manuscript), available at http://ssrn.com/abstract=1326627. This Article excludes references to the later presented paper where the results are identical to what is found in an earlier work
} 
In Factors Influencing Corporate Governance Disclosures: Evidence from Alternative Investment Market (AIM) Companies in the UK, Chris Mallin and Kean Ow-Yong evaluate the disclosure of corporategovernance compliance in 300 AIM corporate annual reports released for financial years ending in 2005 and 2006, and correlate disclosure with company characteristics including percent of institutional ownership, percent of managerial ownership, board size, board independence, nomads that are also brokers, companies formerly listed on the Main Market, companies that are shells without revenue turnover, company size, and gearing ${ }^{45}$ The authors select the sample companies from each industry based on each industry's proportion of the overall AIM population. ${ }^{46}$

In Social Reporting by Companies Listed on the Alternative Investment Market, Sepideh Parsa and Reza Kouhy examine eighteen categories of social information disclosed by one hundred companies listed on the AIM from 2001 through 2003 and correlate disclosure with company age, industry, size, and financial gearing. ${ }^{47}$ Social information includes corporate culture and ethics, environmental issues, equal opportunity, rewards, and charity ${ }^{48}$ Although companies are not required to report most social information, companies choose to disclose this information to increase their reputation among outside stakeholders, such as current or potential investors. ${ }^{49}$ This study scores disclosure through corporate annual reports using eighteen unweighted categories of social information derived from eight categories promulgated by the European Commission. ${ }^{50}$

In Does the Alternative Investment Market Nurture Firm Growth? A Comparison Between Listed and Private Companies, Valérie Revest and Alessandro Sapio compare the productivity of companies listed on the AIM between 1997 and 2008 with their private counterparts. ${ }^{51}$ The authors match limited liability manufacturing firms incorporated in the UK with private

published by The Institute of Chartered Accountants of Scotland or a later work published by The European Journal of Finance. However, there are some instances where the presentation includes additional helpful information.

${ }^{45}$ Chris Mallin \& Kean Ow-Yong, Factors Influencing Corporate Governance Disclosures: Evidence from Alternative Investment Market (AIM) Companies in the $U K, 18$ EUR. J. FIN. 515, 516-22, 525 tbls. 3 \& 4 \& 526 tbl.5 (2012).

${ }^{46}$ Id. at 522.

${ }^{47}$ Sepideh Parsa \& Reza Kouhy, Social Reporting by Companies Listed on the Alternative Investment Market, 79 J. BuS. ETHICS 345, 345 \& 348-50 (2008).

${ }^{48} \mathrm{Id}$. at $350 \mathrm{tbl}$.I.

${ }^{49} \mathrm{Id}$. at 349 .

${ }^{50} \mathrm{Id}$. at 350 .

${ }^{51}$ Valérie Revest \& Alessandro Sapio, Does the Alternative Investment Market Nurture Firm Growth? A Comparison Between Listed and Private Companies, 22 INDUS. \& CORP. CHANGE 953, 954-55 (2013), available at http://icc.oxfordjournals.org/content/22/4/953.full.pdf + html. 
companies, based on age, size, and industry sector. ${ }^{52}$ Using employee productivity, operating revenue, and total assets, the authors compare the growth of the matched companies. ${ }^{53}$ This is a particularly interesting study because it uses an appropriate benchmark of private companies to evaluate AIM performance instead of firms listed on a premier exchange.

In Europe's Second Markets for Small Companies, Silvio Vismara, Stefano Paleari, and Jay R. Ritter evaluate the performance of the AIM, and similar second-tier markets throughout Europe, with Europe's premier exchanges. ${ }^{54}$ The authors use a group of 3,755 IPOs on four of Europe's exchanges, including both first- and second-tier markets; 2,085 of those were on the London Stock Exchange, with 1,642 on the AIM. ${ }^{55}$ Notably, this group excludes simple stock introductions-listing a stock without offering any new or existing shares for sale-which are common on the AIM and other secondary markets in Europe. ${ }^{56}$ This exclusion is likely to remove companies that list on the AIM for the simple purpose of providing a structured liquidity market to existing shareholders without raising funds.

\section{B. Process of Analysis}

Instead of simply presenting observations based on the empirical literature, this Article documents the intermediate research step of charting the underlying statistical correlations. This approach provides other researchers the opportunity to more quickly review the underlying empirical research as whole without reviewing each underlying study. This is a significant contribution to the literature, which to date does not include such a detailed summary of the empirical literature studying the AIM. Additionally, the charting methodology is unique; this approach distills empirical correlations into an accessible representation for researchersshowing only the relationship direction and statistical significance between independent and dependent variables. While the magnitude of a relationship is certainly important, the relationship direction and statistical significance quickly convey empirical trends.

In developing this chart, the author first used simple research techniques to cull through the available scholarly literature to identify articles discussing the AIM. Next, the author reviewed each candidate article closely to determine if the article conducted meaningful statistical analysis, or was simply a recitation of anecdotal evidence, opinion, or other literature. In determining whether a candidate article conducted meaningful

\footnotetext{
${ }^{52} I d$. at $960-61$.

${ }^{53} \mathrm{Id}$. at 961 .

54 Silvio Vismara et al., Europe's Second Markets for Small Companies, 18 EuR.

FIN. MGMT. 352, 353-54 (2012).

${ }^{55}$ Id. at $358-59$ tbl.2.

${ }^{56} \mathrm{Id}$.
} 
statistical analysis, the author looked primarily for regression analysis correlating independent variables with dependent variables. Further, some articles conducted meaningful statistical analysis on several markets, including the AIM. In these cases, the author determined whether he could separate the AIM specific analysis from that of other studied market and included only the analysis relevant specifically to the AIM. Moreover, some articles reported statistical analyses in a format that could not be reliably interpreted for inclusion in the chart and were therefore excluded. ${ }^{57}$

Finally, the author distilled each independent to dependent variable correlation into a simple direction and statistical significance scale, called the rated relationship. If the dependent variable moves in the same direction as the independent variable, that relationship is represented with a plus sign $(+)$. For example, if an increase in the independent variable is correlated with an increase in the dependent variable, this is reported as a positive relationship. Conversely, if the dependent variable moves in the opposite direction as the independent variable, the relationship is reported with a negative sign (-). For example, if an increase in the independent variable is correlated a decrease in the dependent variable, this relationship is reported as negative. In most articles, relationship direction was determined by the sign of the correlation coefficient.

Additionally, each reported relationship is rated for its statistical significance. A relationship with no statistical significance is enclosed in square brackets, for example [+] or [-]. A relationship with a low, but measurable, statistical significance is reported as a single sign: + or -. In most cases, this represents a p-value of less than or equal to 0.1 , but greater than 0.05 , and may have been reported with a single asterisk $\left(^{*}\right)$ next to the correlation coefficient. A moderate degree of statistical significance is reported as two signs: ++ or -- . The standard $\mathrm{p}$-value for this relationship is less than or equal to 0.05 , but greater than 0.01 , or two asterisks $\left(^{* *}\right)$. Finally, the strongest statistical significance is reported as three signs, +++ or - - -; these relationships have a p-value of less than or equal to 0.01 , commonly represented as three asterisks $(* * *)$.

While some correlative relationships are easily converted to the rated relationship scale, others require summarization. Summarization is necessary in some cases because too much detail in one area could quickly overshadow an equally important, albeit more generalized, relationship in another. For example, one study reported correlations between book performance ratios, including return on assets and return on equity, with year zero, one, two, and three after IPO, which results in four correlations for each book performance ratio, and twenty-eight total correlations, most

\footnotetext{
${ }^{57}$ For example, the empirical findings discussed in the text infra accompanying notes 165-167 were not included in the chart because of the irregular presentation in the original publication.
} 
of which indicate the same general relationship..$^{58}$ In this case, and cases similar to it, the chart presents summarized findings. ${ }^{59}$ In this example, return on assets has a positive, but not statistically significant, correlation with years one through three after IPO and has a statistically significant correlation for year zero; these four correlations are combined into one chart entry of.$+^{60}$ The chart only groups correlations when they are generally similar and evidence the same relationship.

Crucially, the chart reports qualitative, but not quantitative, information about each relationship. While some of the reviewed analyses elaborate on the quantitative nature of a relationship, most analyses report only the coefficient. Without more, the value of the coefficient alone does not necessarily reflect in real terms to what degree a given change in the independent variable correlates with change in the dependent variable. It is important to keep this limitation in mind. For example, Vismara et al. reports that an AIM listing is correlated strongly with negative three- and five-year buy-and-hold returns as compared to the FTSE Euromid Index. ${ }^{61}$ While the chart represents this simply as strongly negative (- - -), in real terms the AIM buy-and-hold return, in relation to the benchmark index, is negative $27.5 \%$ at three years and negative $45.7 \%$ at five as compared to $25.3 \%$ at three years on the Main Market. ${ }^{62}$ While the chart accurately represents that the AIM has a strong association with negative buy-and-hold returns, it does not represent the magnitude of that negative association. In this particular case, strong association with very large negative returns is concerning. Therefore, compiling quantitative information about each relationship is an important research goal, which this Article addresses in some cases, but leaves much for another day.

Finally, the chart categorizes each dependent and independent variable. For example, the Book Performance category of dependent variables includes measures such as leverage, return on equity, asset turnover, and similar financial statement measures. As an additional example, the AIM vs. Non-AIM independent variable category includes variables indicating a selection of the AIM instead of, for example, the Main Market of the London Stock Exchange, the NASDAQ, the OTC Pink Sheets, or simply remaining a private company. Explanation of a few example entries is helpful.

\footnotetext{
${ }^{58}$ Khurshed et al., supra note 38 , at 28 tbl.5.

${ }^{59}$ See infra notes 350-358 and accompanying text.

${ }^{60}$ Compare Khurshed et al., supra note 38 , at 28 tbl.5 (correlating return on assets on AIM to years +1 to +3 relative to the IPO), with infra note 354 and accompanying text.

${ }^{61}$ Compare Vismara et al., supra note 54, at 368-69 tbl.5, with infra text accompanying notes 200-201.

${ }^{62}$ Compare Vismara et al., supra note 54, at 353 \&368-69 tbl.5, with infra text accompanying notes $200-201$.
} 


\begin{tabular}{|l|l|l|}
\hline \multicolumn{3}{|c|}{ Example 1: Association between AIM vs. Non-AIM, and Book } \\
Performance \\
\hline $\begin{array}{l}\text { AIM listing instead of Main } \\
\text { Market }\end{array}$ & - - $^{63}$ & $\begin{array}{l}\text { Pre-IPO Cash Flow Return } \\
\text { on Assets }\end{array}$ \\
\hline \multicolumn{2}{|c|}{ Example 2: Association between Ownership and Book Performance } \\
\hline Venture capitalist backing & {$[+]^{64}$} & Delisting \\
\hline \multicolumn{2}{|c|}{ Example 3: Association between AIM vs. Non-AIM, and Market } \\
\hline \multicolumn{3}{|c|}{ Performance } \\
\hline $\begin{array}{l}\text { AIM listing instead of } \\
\text { NASDAQ, Main Market, or } \\
\text { OTC Bulletin Board }\end{array}$ & $--{ }^{65}$ & $\begin{array}{l}\text { Eighteen-month buy-and- } \\
\text { hold return }\end{array}$ \\
\hline
\end{tabular}

In the first example above, selection of the AIM, instead of the Main Market of the London Stock Exchange, has a negative correlation with pre-IPO cash flow return on assets. Cash flow return on assets is a book performance measure and is categorized appropriately. Further, comparing selection of the AIM instead of the Main Market falls into the AIM vs. Non-AIM category. Finally, the relationship is rated - - , which indicates that the variables move in opposite directions and the relationship between the variables has the highest level of statistical significance, typically a p-value of less than or equal to 0.01 as sometimes indicated with three asterisks $(* * *)$. Based on the statistical significance, the reader can have the highest level of statistical confidence in the direction of this relationship.

The second example above indicates that venture capitalist backing has a positive, but statistically insignificant, relationship with delisting. The variables are categorized as Ownership and Survival, respectively. The rated relationship is $[+]$, which means that while the variables move together-backing by venture capitalist is associated with increased delisting - there cannot be any statistical confidence in this relationship. In cases without statistical significance, there are two important possible

${ }^{63}$ Khurshed et al., supra note 38 , at 26 tbl.3.

${ }^{64}$ Espenlaub et al., supra note 28 , at 30 tbl. 9 \& 31 tbl.10.

${ }^{65}$ Gerakos et al., Post-listing Performance, supra note 17, at 198 tbl.3 \& 199-200 tbl.4. 
explanations-either of which could exist in many statistically insignificant correlations. First, the sample size could be too small for a pattern to emerge; there may be a relationship between these variables, but a larger sample will be required to discern a pattern. Second, there may be no reliable relationship between the variables. Based on these two possibilities, it is important not to draw firm conclusions from correlations without statistical significance.

The third example above shows that a listing on the AIM, instead of the NASDAQ, the Main Market, or the OTC Bulletin Board, has a - - rated relationship with eighteen-month buy-and-hold returns. An investor buying stock in a company that lists on the AIM is more likely to find his or her return lower after eighteen months than an investment in another company that chose to list on the NASDAQ, the Main Market, or the OTC Bulletin Board. Based only on this chart entry, however, the investor will not know how much lower. Further investigation into the underlying study reveals that AIM firms underperform a benchmark portfolio by $28.6-33.5 \%$ after twelve months and $42.7-46.2 \%$ after twenty-four months, which is consistent with other research. ${ }^{66}$

\section{ThE AIM Is Not A PREMIER EXCHANGE}

In general, companies listed on the AIM dramatically underperform their counterparts on premier exchanges such as the NASDAQ and the Main Market of the London Stock Exchange. However, the little research that exists comparing AIM companies with private companies or those listed on the OTC Pink Sheets is not conclusive. The empirical findings discussed below show that the AIM is not a premier exchange, but is appropriately dubbed an alternative, or junior, market.

\section{A. AIM Companies Underperform their Premier Exchange Counterparts}

Several studies compare the AIM to other exchanges or indices such as the Main Market, the FTSE Euromid Index, the NASDAQ, and the OTC Bulletin Board. The findings in these studies indicate that the AIM has four substantial shortcomings when compared with these benchmarks.

First, the AIM has a strong association with lower buy-and-hold returns performance for all measured time periods. ${ }^{67}$ Two different author groups and three studies confirm this finding using a variety of time

\footnotetext{
${ }^{66} I d$. at 196.

${ }^{67}$ See Gerakos et al., Post-listing Performance, supra note 17, at 198-99 tbl.3, 199-200 tbl.4, 203 tbl.5, 205 tbl.7, 207 tbl.8 \& 208 tbl.9; see generally Vismara et al., supra note 54 .
} 
periods, measures, and benchmarks. ${ }^{68}$ AIM firms underperform premier exchange benchmarks by $28.6-33.5 \%$ at twelve months and $42.7-46.2 \%$ at twenty-four months as found by one study and $27.5 \%$ at three years and $45.7 \%$ at five years as found by another. ${ }^{69}$ These are perhaps the most disturbing AIM statistics. Further, performance is lower for U.S. companies exclusively listing on the AIM as compared to companies listing on an SEC-regulated exchange. ${ }^{70}$

While lower market performance-decreased share price over time-may indicate that an AIM company is less economically productive in real terms, it may also indicate that the company was initially overpriced. In the case of this later scenario, it is not the real economic performance that has decreased when stock performance decreases, but instead the investor confidence in future profits as investors price the same stock lower than they did in the past. On the AIM, each of these, to some degree, affects the rate of return.

One problem with analyzing AIM performance in aggregate is that the analysis could gloss over the unusually high returns generally expected in a more risky market. ${ }^{71}$ In addressing this concern, one study used several trading patterns to identify high performing firms, including doubling of share value over the three analyzed time periods, firms upgrading from the AIM to the Main Market, and positive returns immediately prior to delisting-indicating a good delisting such as a merger. ${ }^{72}$ However, even when accounting for success indicated by these trading patterns, the authors concluded that "there is little evidence that highflying firms use the AIM listing as a stepping stone to positive outcomes."73

Additionally, there is a strong association with poor market performance for companies that raise capital at the time of listing-which most AIM companies do not do-and for those that have retail-investor ownership. ${ }^{74}$ The interplay between these two findings is startling for small investors. It is unlikely that retail investors will have an opportunity to buy shares in a company before the IPO. However, new shares issued at an IPO provide an opportunity for retail investors to buy into the company. These

${ }^{68}$ See Gerakos et al., Listing Choices, supra note 34, at $19 \& 52$ tbl.4; see also id. at $26 \& 60$ tbl. 12 .

${ }^{69}$ Compare Gerakos et al., Post-listing Performance, supra note 17, at 196, 198

tbl.3 \& 199-200 tbl.4, with Vismara, et al., supra note 54, at 368-69 \& 369 tbl.5.

${ }^{70}$ See Gerakos et al., Listing Choices, supra note 34, at 34-35 \& 61 tbl.13.

${ }^{71} I d$. at 24.

${ }^{72}$ See id.at $24-25$.

${ }^{73} \mathrm{Id}$. at 25.

${ }^{74}$ See Gerakos et al., Post-listing Performance, supra note 17, at 207 tbl.8 \& 211 tbl.11. 
findings indicate that when investors take this opportunity, there is a strong association with poor market performance.

Second, the AIM has a strong association with poor liquidity, measured by the bid-ask spread and the number of days without trading, as indicated by a zero return on a given day ${ }^{75}$ However, larger firms on the AIM do enjoy better liquidity ${ }^{76}$ Poor liquidity is a bad pairing with poor buy-and-hold returns because investors cannot reasonably expect to divest quickly or at a reasonable price once they determine that the poor returns will continue. Moreover, poor liquidity masks actual performance. When there are fewer trades, the individual situations of the buyers and sellers begin to affect the price more. For example, a seller who is desperate to sell for a reason external to stock price, such as a personal need for cash, will take a lower price simply for the benefit of selling. Because this trade is a larger portion of the overall trading activity, the distortive effect of the individual trader's motive for selling at a given price is not as diluted as it is in a market with high trading volume.

Third, the AIM has a strong association with low survival. ${ }^{77}$ AIM firms are more likely to fail than firms on the other exchanges.$^{78}$ However, the failure rate is not as bad as SEC Commissioner Roel Campos alleged: thirty percent within a year. ${ }^{79}$ In the short term, up to thirty-five percent of companies fail in the twenty-four months after IPO on the AIM ${ }^{80}$ Failure rates differ widely by sector. IPOs in the utilities sector had no failures during the studied period while IPOs in the financial sector failed the

${ }^{75}$ See Gerakos et al., Listing Choices, supra note 34, at 56-57, 60-61, tbls. 8, 9, 12 $\& 13$.

${ }^{76}$ See id. at $28 \& 56$ tbl. 8 ; see also id. at 32-33 \& 60 tbl.12. Nomad selection may also affect liquidity and market performance, although only slightly. Id. at 30-31. A nomad serving as the broker has a strong association with better liquidity. Id. Further, the nomads with higher average one year returns for their prior IPO companies are strongly associated with better eighteen-month buy-and-hold returns. Gerakos et al., Post-listing Performance, supra note 17, at 210 tbl.10. However, a more experienced nomad is strongly associated with poor liquidity. Gerakos et al., Listing Choices, supra note 34, at 58 tbl.10. And a nomad with more delistings in its past is strongly associated with poor liquidity. $I d$.

${ }^{77}$ Gerakos et al., Post-listing Performance, supra note 17, at 203 tbl.5 \& 204 tbl.6.

${ }^{78}$ Gerakos et al., Listing Choices, supra note 34, at 31.

${ }^{79}$ Compare Cohen, et al., supra note 4, at 1, with Espenlaub et al., supra note 28, at 20.

${ }^{80}$ Espenlaub et al., supra note 28 , at 20-21. Several company characteristics at the time of IPO are associated with long-term-five year-survival. $I d$. at $22 \& 30$ tbl.9. Older age, larger size, and incorporation in the UK all correlate to higher chances of long-term survival. Id. at 22-23 \& 30 tbl.9. Further, firms operating in financial, cyclical service, and resource sectors had higher long-term survival rates than those operating in the technology sector. Id. Whether the firm was backed by venture capitalist or the size of initial returns from the IPO are not significantly correlated with long-term survival. Id. 
most. ${ }^{81}$ Additionally, United Kingdom domestic firms and firms without venture capitalists involved performed better than their counterparts. ${ }^{82}$

Additionally, there is a strong association with a shorter time from listing to delisting for AIM companies. ${ }^{83}$ AIM firms, on average, have a shorter time to delisting than firms that list on the NASDAQ ${ }^{84}$ Similarly, firms on both the Main Market and the OTC Bulletin Board, while having shorter times to delisting than those on the NASDAQ, have longer times to delisting than firms on the AIM ${ }^{85}$ An interesting comparison, however, is the close score of AIM companies (79.8\%) to Main Market companies $(69.3 \%){ }^{86}$ This score indicates that the survival rate of Main Market companies is closer to that of AIM companies than that of NASDAQ companies.

Fourth, and finally, few companies graduate from the AIM to the Main Market. From 2000 to 2004 only thirty companies transferred from the AIM to the Main Market. ${ }^{87}$ During the same time period, 130 transferred from the Main Market to the AIM, ${ }^{88}$ while 594 new firms listed on the AIM and 100 listed on the Main Market. ${ }^{89}$ Another study observed that less than one percent of companies listed on the AIM transfer to the Main Market. ${ }^{90}$

The shortcomings of the AIM are significant. These findings indicate that the AIM is not a premier exchange based on the stock performance, liquidity, rate of failure, and eventual graduation to the Main Market. The AIM cannot compete with premier exchanges and should not be viewed as an equitable alternative, but indeed a different kind of market altogether.

\section{B. Research is Inconclusive when Comparing AIM Performance with Private Companies and the OTC Pink Sheets}

There is little research on how AIM companies compare with their private counterparts. But the research that exists indicates that AIM companies do better than their private counterparts-AIM companies are associated with more employees, more revenue, and more assets. ${ }^{91}$

\footnotetext{
${ }^{81} I d$ at 20.

82 Id. at 21.

${ }^{83}$ Gerakos et al., Listing Choices, supra note 34 , at 32.

${ }^{84} \mathrm{Id}$. at 32 \& $59 \mathrm{tbl} .11$.

${ }^{85} \mathrm{Id}$. at 32.

${ }^{86}$ See id. at 32, 59 tbl.11.

${ }^{87}$ Board \& Wells, supra note 24 , at 212 tbls. 3.1 \& 3.3 .

${ }^{88} \mathrm{Id}$.

${ }^{89}$ See Gerakos et al., Post-listing Performance, supra note 17, at 195 tbl.1 (adding listings for AIM and the Main Market for years 2000 for 2004).

${ }^{90}$ Parsa \& Kouhy, supra note 47, at 353 tbl.V.

${ }^{91}$ Revest \& Sapio, supra note 51, 968-69, 977 tbl.A3 \& 978-79 tbl.A4.
} 
However, there is some question about how statistically significant these data are. ${ }^{92}$ One notable negative finding, however, is that employee productivity is lower in AIM companies. ${ }^{93}$

Additionally, the AIM appears to underperform the OTC Pink Sheets, though the author cautions against any firm conclusions. ${ }^{94}$ One study indicates that an AIM listing, instead of OTC Pink Sheets, has little association with poor market performance, as measured with buy-and-hold returns. ${ }^{95}$ However, another study by the same authors indicates that an OTC Pink Sheets listing, as opposed to AIM, has a stronger association with better market performance. While these data agree that the OTC Pink Sheets may perform better, they do not agree on how statistically significant this association is. Further research is required. One notable negative finding, however, is that companies listed on the AIM are more likely to fail before companies listed on the OTC Pink Sheets. ${ }^{96}$ This is particularly troubling because the OTC Pink Sheets is an unregulated market. ${ }^{97}$

\section{THe AIM BRIDGeS the GaP BETWEen PRIVATE OWNERSHIP AND PREMIER LISTING}

Despite the poor performance on the AIM as compared to premier exchanges, the AIM nevertheless fills a niche. Ownership, control, and leverage for AIM companies do not change substantially during an IPO; that makes AIM companies different. AIM companies are not competing at the level expected of companies listed on a premier exchange, but the AIM fills the space between a premier exchange listing and remaining strictly a private company. Out of this middle ground, the AIM can play two important roles for listed companies: First, the AIM can act as an on-ramp to the Main Market. Second, the AIM can provide a structured liquidity market for existing shareholders.

\footnotetext{
$92 I d$.

${ }^{93} I d$.

${ }^{94}$ Compare Gerakos et al., Listing Choices, supra note 34, at 60 tbl.12, with Gerakos et al., Post-listing Performance, supra note 17, at 205 tbl.7 \& 206.

${ }^{95}$ Gerakos et al., Listing Choices, supra note 34, at 60 tbl. 12.

${ }^{96}$ Gerakos et al., Post-listing Performance, supra note 17, at 205-06 tbl.7.

${ }^{97}$ See OTC Market Group Inc., Our Three Tiered Marketplaces, OTCMARKETS, http://www.otcmarkets.com/learn/otc-market-tiers (last updated April 29, 2014) (finding that the "No Information" designation of OTC Pink "[i]ndicates companies that are not able or willing to provide disclosure to the public markets - either to a regulator, an exchange or OTC Markets Group").
} 


\section{A. AIM IPOs are Different than Premier Exchange IPOs \\ Because Ownership, Control, and Leverage Do Not Substantially Change}

In contrast to traditional IPOs, major shareholders of AIM companies do not divest ownership and control during an IPO. ${ }^{98}$ Before an IPO on either the AIM or a premier exchange, a firm's equity is concentrated in a few significant shareholders, including management and venture capitalists. ${ }^{99}$ IPOs on the Main Market typically result in significant dilution of ownership, whereas IPOs on the AIM typically do not. ${ }^{100}$ After an IPO on the AIM, institutional investors own on average almost thirty percent and managers hold almost twenty-four percent, leaving only fortysix percent-minority control-for other investors. ${ }^{101}$ Consolidated ownership is a result, in part, from the mandatory one-year lockup for companies that have not had revenue for at least two years. ${ }^{102}$

Ownership and control of AIM companies is consolidated in three shareholder groups. First, an AIM listing is strongly associated with a higher percentage of ownership by the board before and after the IPO. ${ }^{103}$ Further, AIM boards divest less at IPO. ${ }^{104}$ The median reduction in ownership for the board on the Main Market is twenty-nine percent as compared to twenty-six percent on the AIM-a three-percent difference. ${ }^{105}$

Second, the top four shareholders in an AIM company have a higher ownership percentage after an IPO than those shareholders have in a Main Market company. ${ }^{106}$ The top four shareholders of a firm pre-IPO on the Main Market hold a majority interest over the firm, but post-IPO the top four shareholders typically lose control. ${ }^{107}$ In contrast, the top four shareholders of IPO firms on the AIM typically do not lose their majority

\footnotetext{
${ }^{98}$ Khurshed et al., supra note 38 , at 13 \& 27 tbl.4.

${ }^{99} \mathrm{Id}$. at 13.

${ }^{100} \mathrm{Id}$.

${ }^{101}$ Mallin \& Ow-Yong, supra note 45, at 526.

${ }^{102}$ LONDON STOCK EXCH., AIM RULES FOR COMPANIES 4 (Feb. 2010), available at http://www.londonstockexchange.com/companies-and-

advisors/aim/advisers/rules/aim-rules-for-companies.pdf:. Where an applicant's main activity is a business which has not been independent and earning revenue for at least two years, it must ensure that all related parties and applicable employees as at the date of admission agree not to dispose of any interest in its securities for one year from the admission of its securities. Id.

${ }^{103}$ Khurshed et al., supra note 38 , at 27 tbl.4.

${ }^{104} \mathrm{Id}$.

${ }^{105} \mathrm{Id}$.

${ }^{106} \mathrm{Id}$.

${ }^{107} \mathrm{Id}$.
} 
interest after the IPO. ${ }^{108}$ Like their board counterparts, the top four shareholders do not divest as much of an AIM company as they would in the Main Market. ${ }^{109}$ The median reduction in ownership for the top four shareholders on the Main Market is thirty-four percent where the median reduction in ownership on the AIM is twenty-seven percent-a sevenpercent difference. ${ }^{110}$

Third, venture capitalist investors in AIM companies divest less of their ownership at IPO than they do in Main Market companies. ${ }^{11}$ For venture capitalists, the reduction in ownership on the Main Market is fortyone percent as compared to twenty-six percent on the AM-a fifteenpercent difference. ${ }^{112}$

Moreover, two empirical findings confirm the different ownership and control structure on the AIM. First, in AIM IPOs, companies offer a smaller portion of existing shares relative to the whole offering; and many IPOs on the AIM do not offer any existing shares. ${ }^{113}$ Second, AIM IPOs issue a smaller percentage of new equity than Main Market IPOs. ${ }^{114}$ That means that the ownership of current shareholders is diluted less than on the Main Market. Overall, these correlations indicate that AIM IPOs simply offer fewer shares-existing or new-which is consistent with the much higher number of IPOs on the AIM with lower, or at most comparable, total capital raised as compared to premier exchanges. ${ }^{115}$

Additionally, in contrast to companies on the Main Market, companies do not permanently deleverage after an IPO on the AIM. IPOs and debt are two significant financing tools companies use to fund growth. ${ }^{116}$ After an IPO on the Main Market, companies permanently reduce their leverage thereby exchanging one mode of finance for another-debt for equity. ${ }^{117}$ In contrast, after an IPO on the AIM, leverage decreases temporarily, but later returns to pre-IPO levels. ${ }^{118}$ Higher leverage is consistent with less equity offered at IPO; AIM companies are not raising enough cash at IPO to satisfy their financing needs.

Consolidated ownership and higher leverage after an IPO on the AIM is significant when evaluating the underperformance of the AIM in comparison to premier exchanges. A substantial motivation for companies

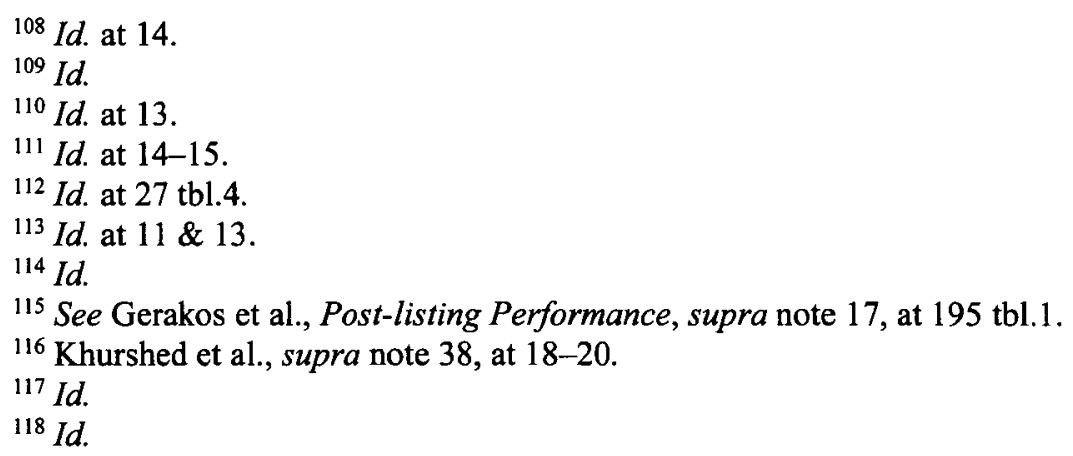


going public on a premier exchange is to provide existing investors with an opportunity to cash out of the venture. Further, these IPOs commonly provide a significant influx of cash to the company for investment and development-or at least for converting debt to equity. However, since companies do not achieve these goals with an IPO on the AIM there must be some alternative motivation-value-behind this decision. There are two probable motivations for these companies listing on the AIM that undermine the importance of the AIM's underperformance as compared to premier exchanges: companies may seek to use the AIM as an on-ramp to a premier public company status-including listing on the Main Market-or may simply be looking for a structured liquidity market and a place to grow.

\section{B. The AIM as an On-Ramp to Premier Public Company Status}

Some companies use the AIM as an on-ramp to a premier public company status, including perhaps a listing on the Main Market. AIM companies are smaller than their Main Market counterparts; the market capitalization is smaller and the IPO offer size is also smaller. ${ }^{119}$ Additionally, AIM companies do not permanently deleverage after an IPO. ${ }^{120}$ Finally, ownership and control remain consolidated in a few major shareholders. ${ }^{121}$ Consistent with these findings are the strong associations between managerial ownership and less institutional ownership, and fewer assets and fewer nonexecutive directors. ${ }^{122}$ However, as company assets grow, AIM companies, which were small and immature after their IPO, develop into mature companies with similar characteristics to companies listed on premier exchanges. As AIM companies grow, five significant changes occur.

First, bigger companies are owned and controlled by outsiders. With more assets, board ownership decreases, institutional investor ownership increases, and the size of the board grows. ${ }^{123}$ New board members are outsiders, as would be preferred by outside investors, and they do not hold shares. ${ }^{124}$

Second, bigger companies deleverage. With more assets, boards grow, companies disclose more corporate governance standard compliance,

\footnotetext{
119 Khurshed et al., supra note 38 , at 26 , tbl.3.

${ }^{120} \mathrm{Id}$. at 18 .

${ }^{121}$ Id. at $13 \& 27$ tbl.4.

122 See Mallin \& Ow-Yong, supra note 45, at 527 tbl.6.

${ }^{123}$ Id.; see also MALLIN \& OW-YONG, supra note 41, at 89 tbl.5.5; Mallin \& OwYong, supra note 45 , at 527 tbl.6.

${ }^{124}$ MALLIN \& OW-YONG, supra note 41, at 89 tbl.5.5; Mallin \& Ow-Yong, supra note 45 , at 527 tbl.6.
} 
and fewer directors hold shares. ${ }^{125}$ However, these big company characteristics are inconsistent with high leverage or gearing; instead, higher gearing is associated with a smaller percent of nonexecutive directors-who are less likely to hold shares-and less disclosure of corporate governance compliance. ${ }^{126}$ As the number of outside stakeholders grows, company officers must reduce risk-leverage-and provide more conservative but consistent growth. Moreover, higher leverage, which exists in smaller companies, is associated with higher sales growth. ${ }^{127}$ As the leverage decreases based on increased assets and outside stakeholders, sales growth decreases as well, resulting in a strong association between higher existing sales-indicating a bigger company-and poor sales growth. ${ }^{128}$

Third, bigger companies become more transparent. As the number of external stakeholders grows through the addition of independent directors, institutional owners, and generally less inside control, companies begin to disclose like their premier exchange counterparts. Transparency increases in two areas: social information and standards of corporate governance compliance. Increased size leads to a higher disclosure rate of social information. ${ }^{129}$ The more employees or creditors a company has the more social information the company is likely to disclose. ${ }^{130}$ This behavior is similar to what is observed in larger, more studied companies. ${ }^{131}$ Despite the limited resources in smaller companies, companies listed on the AIM with a significant number of external stakeholders disclose social information just like larger companies with access to more resources. ${ }^{132}$ Some areas of particularly high disclosure include a company's principal activity, corporate governance, reputation or branding, environmental impact, and social responsibility. ${ }^{133}$ However, there is little transparency about ethical issues and investment. ${ }^{134}$ Additionally, disclosure rates by industry, which are closely associated with company size, confirm that size strongly affects transparency. ${ }^{135}$

Additionally, increased size leads to more transparency in corporate governance. Companies listed on the AIM are not required to comply, let

\footnotetext{
${ }^{125}$ Mallin \& OW-YonG, supra note 41, at 89 tbl.5.5; see also Mallin \& Ow-Yong, supra note 45 , at 527 tbls. $6 \& 7$.

${ }^{126}$ See Mallin \& Ow-Yong, supra note 45, at 527 tbls. 6 \& 7; see also MALLIN \&

OW-YONG, supra note 41, at 90 tbl.5.6.

${ }^{127}$ See Colombelli, supra note 26 , at 21 tbl.3 \& 22 tbl.4.

${ }^{128}$ See id.

${ }^{129}$ Parsa \& Kouhy, supra note 47, at 356 tbls.IX \& X.

${ }^{130}$ See id.

${ }^{131}$ See id. at 356.

132 See id. at 357.

${ }^{133}$ See Parsa \& Kouhy, supra note 47, at 351-52 tbl.II.

${ }^{134}$ See id.

${ }^{135}$ See id. at 354.
} 
alone disclose compliance, with corporate-governance standards. ${ }^{136}$ However, the Quoted Companies Alliance (QCA) has promulgated the Guidelines on Corporate Governance for AIM Companies. ${ }^{137}$ While some AIM companies may voluntarily comply with these guidelines without disclosing their compliance, companies that disclose compliance demonstrate corporate maturity and thereby benefit from a stronger reputation. ${ }^{138}$ The QCA guidelines recommend audit, remuneration, and nomination committees, independent board members, internal controls, and other generally accepted corporate governance practices. ${ }^{139}$ Company disclosure scores - based on the number of guidelines for which companies disclose compliance-range from two to twenty-three, the maximum possible score, with an average of just over thirteen. ${ }^{140}$ Moreover, companies with larger or more independent boards are more likely to disclose corporate-governance-standard compliance. ${ }^{141}$ Larger companies or companies transferring from the Main Market to the AIM are more likely to disclose compliance. ${ }^{142}$ And companies that are not shells are more likely to disclose compliance. ${ }^{143}$ However, the percentage of institutional or manager ownership and whether a company's nomad was also a broker had no statistically significant relationship with disclosure rate. ${ }^{144}$

Fourth, companies where insiders divest ownership provide a better stock return. When there is net selling by insiders-insiders divest more ownership than they acquire - there is an association with better buy-andhold returns as compared to the AIM average. ${ }^{145}$ These companies still suffer the first month negative correction common to all AIM IPOs; however, these companies have a moderate association with better buy-andhold returns, as compared to the respective market average, from two to eighteen months, of their Main Market counterparts. ${ }^{146}$ The association with better than average returns is confirmed, although not as strongly, by an association with better than average buy-and-hold returns at twelve, twentyfour, and thirty-six months. ${ }^{147}$ Not only do these companies perform better, as compared to the market average, than Main Market companies, but these firms have a stronger association with better than average returns than companies where insiders on balance acquire more ownership over the first

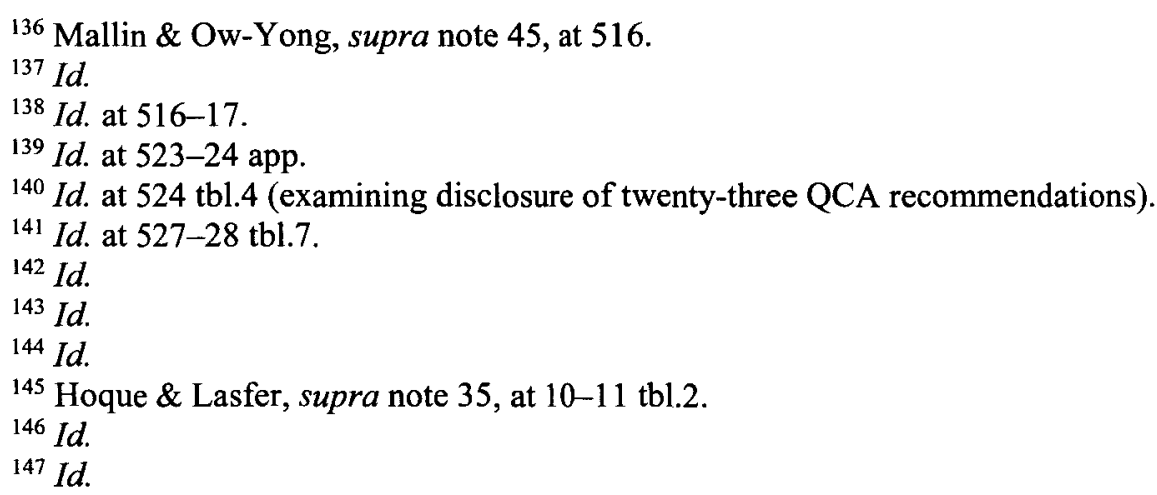


thirty-six months or where they conduct no net trading. ${ }^{148}$ Net trading by insiders is also consistent with the change in ownership and control as a company grows; in order for control and ownership to move from insiders to outsiders, insiders must sell their shares or have their ownership diluted.

However, companies do not have unlimited time to succeed. Worse than average market performance beginning at eighteen months after IPO indicates that investors eventually lose confidence, and begin to devalue the company. There is a strong association with worse than market average performance from nineteen to thirty-six months. ${ }^{149}$ Also, even though not statistically significant, there is an association with above average performance for these companies at six, twelve, and two- through eighteenmonth buy-and-hold returns. ${ }^{150}$ Then at twenty-four and thirty-six months, the association flips to below average returns. ${ }^{151}$ These data indicate that AIM companies have a short presumption of high flying. When the presumption runs out after a year and a half to two years, the market corrects the price down to reflect the lesser expectation of future success.

Fifth, bigger companies grow out of the high-growth phase typical of the small companies listing on the AIM. AIM companies are in a highgrowth phase immediately before and immediately after an IPO. Over the period from three years pre-IPO to three years after, on average, AIM firms grow significantly in terms of sales, total assets, and capital expenditures. ${ }^{152}$ Growth is particularly significant around the IPO and continues thereafter, following the expected S-curve pattern for small companies. ${ }^{153}$ Several small company characteristics - which are lost as the company maturesare associated with this high-growth phase. ${ }^{154}$ Younger and smaller companies are more likely to experience high-growth. ${ }^{155}$ Companies with

$148 \mathrm{Id}$.

149 Id.

${ }^{150} \mathrm{Id}$.

${ }^{151} I d$.

${ }^{152}$ Colombelli, supra note 26 , at 10-11. Small, young companies led by young well-educated CEOs who have taken control from the founder grow more than others. Id. at 21 tbl.3, 22 tbl.4\& 26 . Additionally, graduating from the AIM to the Main Market is associated, strongly in one case, with board quality. These companies have nonexecutive board chairmen, a higher percent of nonexecutive directors, and a larger board in the three years preceding an IPO. Vismara et al., supra note 54 , at $380-81 \& 380 \mathrm{tbl} .9$. A large board is the strongest association of the three. $I d$. at 381 . Other management characteristics evaluated but found to have no statistically significant correlation with growth include board education, CEO research, and CEO experience. Id. at 366 tbl.4. Finally, there is no statistically significant correlation between firm growth and the participation of venture capital. Colombelli, supra note 26, at 22 tbl.4.

${ }^{153}$ Colombelli, supra note 26, at 12 fig. 1 .

154 Id. at 24.

$155 \mathrm{Id}$. 
higher leverage also experienced higher growth. ${ }^{156}$ The most statistically significant firm characteristic associated with firm growth is firm size. ${ }^{157}$ Conversely, a CEO who is also the firm's founder has a negative impact on growth. ${ }^{158}$

Companies that are not in a high-growth phase and list on premier exchanges typically suffer a post-IPO slump. ${ }^{159}$ Company performance, as measured by return on assets ("ROA") and return on equity ("ROE"), permanently declines after IPOs on the Main Market. ${ }^{160}$ In contrast, ROA and ROE increase or experience no statistically significant changes after IPOs on the AIM. ${ }^{161}$ No statistically significant change occurs for cash flow return on assets ("CFROA"), return on sales ("ROS"), and asset turnover ("AT") after IPOs on either market. ${ }^{162}$ Finally, in contrast to the AIM, capital expenditures divided by assets decreases after an IPO on the Main Market, indicating that company investment slows down after an IPO on the Main Market. ${ }^{163}$

Even with these five significant changes in bigger companies, less than $1 \%$ of the companies listed on the AIM eventually graduate to the Main Market, the natural premier exchange to which an AIM company would transfer. ${ }^{164}$ However, for those companies that do graduate, there is minimal effect on performance. The effect of switching from the AIM to the Main Market is relatively small in both the short and long term. ${ }^{165}$ There is a slight long-term bump in performance $(0.1 \%)$ for the companies that switch to the AIM from the Main Market and a slight long-term decrease in performance $(-1.5 \%)$ for the small number of studied companies that switch to the Main Market from the AIM. ${ }^{166}$ However, based on the very small data sample-117 switching to the AIM and 17 switching to the Main Market - these changes in performance are statistically suspect. ${ }^{167}$ Limited change in performance means that an AIM company that transferred to the Main Market was already performing like a Main Market company before it made the switch.

These data indicate that it is the company growth, not the market or regulatory model, that prepares companies for a premier exchange listing.

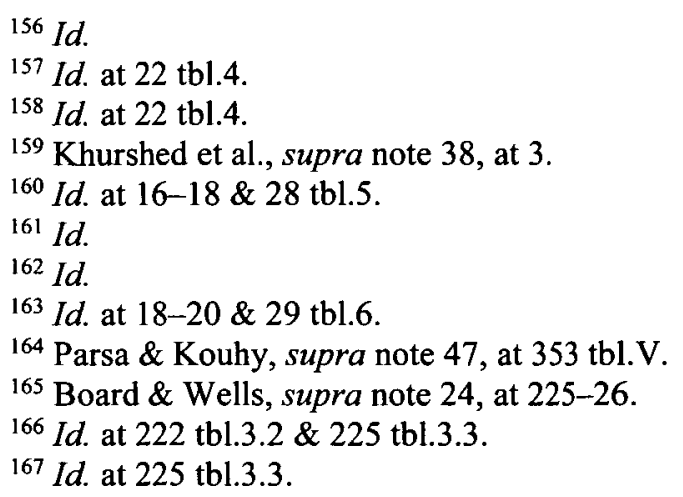


The AIM, which is flexible enough to list both small and large companies, allows small companies to gradually mature in a public market environment. When a company is ready to transition to a premier exchange, the transition is smooth. Additionally, companies that could transition to a premier exchange may instead simply stay listed on the AIM to take advantage of the lighter regulatory burden while still enjoying a reputation similar to those listed on premier exchanges.

\section{The AIM as a Structured Liquidity Market}

For those companies that cannot or do not want to list on a premier exchange, the AIM provides value for shareholders as a structured market good enough for liquidity. Companies and their shareholders benefit when there is a secondary market available for shares. New investors are more likely to infuse cash, with the hope of being able to sell shares in the future. Existing investors asked to increase their investment are less likely to feel backed into a corner when they can already sell their existing shares. Further, companies are able to provide stock compensation more easily to employees, costing the company less than cash compensation and aligning the interests of employees with the success of the company. The employees value stock compensation more when there is a secondary market available than if they are stuck with shares that are difficult to sell. Some of these benefits are available for private companies using issuer-sponsored secondary markets, ${ }^{168}$ but the AIM, as a public, structured, and regulated exchange, can provide more value for investors and companies. There are five ways the AIM provides value to shareholders as a structured public marketplace that private markets cannot offer.

First, the AIM reduces the transaction cost. The AIM is operated by the London Stock Exchange, ${ }^{169}$ no doubt an expert in operating world-class exchanges. Investors on the AIM are therefore able to enjoy all the benefits of this expertise, which results in low transaction friction and wide availability. ${ }^{170}$ Investors, no matter who they are, are able to buy and sell on the AIM without the need of special broker expertise, issuer-sponsored secondary markets, or a difficult search for willing counterparties in an opaque private market. ${ }^{711}$ The importance of reducing transaction friction cannot be overstated. Not only can substantial transaction barriers exist in the private market, but the relative burden of those barriers is more significant in a market with lower volume and more risk because investors recognize that there are additional costs and barriers to getting out of an investment that has already sustained losses. Further, because the overhead

\footnotetext{
168 See About SharesPost, supra note 7; Secondary Transactions, supra note 7.

${ }^{169}$ Stuttard, supra note 8.

${ }^{170}$ See LSE, Growth Market, supra note 10.

${ }^{171}$ See id. at 6.
} 
costs of sustaining the market are shared among the many companies on the AIM and, indeed, the whole London Stock Exchange, these companies get the benefit of an economy of scale even though the individual scale of any one company would never sustain similar transaction benefits. While secondary market providers such as SharesPost or SecondMarket may provide similarly lowered transaction costs, the expertise of the London Stock Exchange is a huge asset for the AIM, which these other providers do not enjoy. ${ }^{172}$

Second, the AIM provides confidence in the class of securities held. Private stock holdings may be inhibited with special stock classes, rules, or restrictions. ${ }^{173}$ However, on the AIM, stock holdings are standardized, giving confidence that what an investor is buying or selling is of a specifically admitted class of securities with clear limitations and rights. ${ }^{174}$ Further, companies can only list stock that conforms to the generally accepted standards of common stock. ${ }^{175}$ An investor selecting from one of two listed companies can be confident that while the stocks may differ in price and the underlying value of the company, they represent similar property interests. In contrast, a private company facilitating a private secondary stock market for its shareholders can set its own rules and need not conform to generally accepted standards. ${ }^{176}$

Third, the AIM provides pricing transparency. With a public clearing house of transaction information, investors are able to track and appropriately price stocks. ${ }^{177}$ In contrast, an investor in private securities may not know at what price the securities have recently traded. ${ }^{178}$ While this information may not be as clear as it is on a premier exchange, it is clearer than a strictly private market. Further, even though limited liquidity will reduce pricing accuracy, the increased access to transaction data allows investors to better estimate an accurate price because, presumably, statistical analysis of previous trading patterns on similarly less liquid

${ }_{172}$ See About SharesPost, supra note 7; Secondary Transactions, supra note 7.

${ }^{173}$ See Colin Aaronson, IPO Groundwork in A GUIDE TO AIM 20 (Nigel Page ed., 2010).

174 See id.

175 See id.

${ }^{176}$ Secondary Transactions, supra note 7 ("Configure your transaction according to your parameters - who can buy, who can sell, how much, and the price.").

177 See AIM Indices, London Stock Exchange,

$\mathrm{http}: / / \mathrm{www}$.londonstockexchange.com/exchange/companies-and-

advisors/aim/indices/indices.html (last visited Dec. 3, 2014).

${ }^{178}$ Cf. Secondary Transactions, supra note 7 ("You control access to the secure environment for both buyers and sellers."). Data privacy with regard to a secondary market for a private issuer's shares is especially important because the issuer does not want outside analysts evaluating trading patterns of insiders to determine company health or worth. However, without outside expert analysis, investors cannot be sure of accurate pricing. 
stocks will inform an appropriate price estimation. Moreover, the pricing transparency of an individual stock is increased in the context of a broader market of similar companies. Because investors can quickly compare one company against another, an overpriced stock based on the performance fundamentals can be more quickly identified than if it were operating in more isolation as a private company.

Fourth, the AIM provides an active regulatory authority that will respond to maintain the reputational integrity of the market. While the AIM must balance regulation with the goal of lower barriers to listing, it will staunchly protect its interest in the operation of the exchange. The almost twenty-year survival of the exchange through the dot com bubble of 2000 and the great recession of 2008 are a testament to the AIM's ability to adapt to meet difficult times. No doubt AIM companies suffered, and many failed, during these financial downturns, ${ }^{179}$ but the AIM continues to flourish as a reputable exchange for growing companies. Essential to the reputational integrity of the exchange is adequate oversight of listed companies. By providing just enough regulatory oversight, companies and investors find value and continue to list and invest. Further, this regulatory authority is able to respond to patterns of abuse and industry best practices to prevent future failures without burdening growth.

Fifth, by listing on the AIM, companies subject themselves to greater external oversight than private companies, further aligning the interests of the company with those of its investors. By listing, companies subject themselves to the regulatory oversight of a nomad and the London Stock Exchange. ${ }^{180}$ Companies can be forcibly delisted for misconduct, a swifter punishment than securities fraud, for example, which could take years to resolve in court. ${ }^{181}$ Further, companies must bring in an outside nomad as an internal regulator. ${ }^{182}$ While the company selects its own nomad and may nevertheless obstruct thorough investigation, an outsider with inside access increases the opportunity for exposure of corporate wrongdoing in a similar way an independent auditor does.

For companies seeking a structured liquidity market, the AIM can be a good match. The AIM can provide the right alternative for a small company seeking to grow, but which is not large enough to list on a premier exchange and whose shareholders demand more than a private market. While investors with large holdings will not be able to completely divest on the AIM, the exchange provides liquidity around the margins. For example, for a founder who holds many shares and does not want to fully exit the venture, but nevertheless needs some cash, the AIM provides a way to sell

\footnotetext{
${ }^{179}$ See Gerakos et al., Listing Choices, supra note 34, at 48 tbl.1.

${ }^{180}$ LONDON STOCK EXCHANGE, supra note 170, at 6.

${ }^{181}$ See John Cowie, Being on AIM in A GUIDE TO AIM 60 (Nigel Page ed., 2010)

${ }^{182} I d$.
} 
some shares. Similarly, an employee who participates in stock compensation can sell some shares to convert that compensation into cash. Particularly for a company that uses stock compensation for many employees, the ease of access for these investors allows unsophisticated employees to trade shares more easily. By allowing retail investors to trade on the AIM, employees do not have to worry about going through a specific issuer provided portal to sell their shares. Instead, each employee, who is likely a retail investor in level of sophistication, can use his own investment broker to buy and sell shares.

Moreover, while major investors may not want to completely divest from the venture, a growing, liquid market allows them to gradually divest over time. Especially for investors who hold large interests in a company, but are not wealthy enough to have other investments sufficient to diversify their holdings, slow divestment provides a way to diversify. For example, an early member of a company may be quite wealthy based on his holdings in the one company. However, since such company ownership is the primary object of wealth, an individual's financial future is closely tied to the success of the company. Such an individual may desire to diversify wealth somewhat to hedge risk exposure in the company. While this investor may prefer a traditional IPO that creates a large market for shares, he is likely to jump at the opportunity of a limited market earlier.

Additionally, company owners may have a legitimate reason for not wanting to go through the traditional IPO process, but nonetheless benefit from a limited, liquid market. Recently, several notable companies have gone private to realize the benefits of consolidated control. ${ }^{183}$ These companies, or those that stay private for the same reason, can benefit from providing some liquidity. ${ }^{184}$ For example, stock compensation for employees and ownership consolidation.

Finally, if a company utilizes the AIM as a structured liquidity market, the company may trade in its own stock to grease the market for the benefit of its shareholders. For example, a company may identify a target stock price based on an internal valuation of the company. The company may allocate some funds for the purpose of trading in its own stock to maintain this price, buying when the market price is below the target and selling when it is above. Additionally, the company may simply buy or sell stocks to provide some market volume. Assuming the company targets a net break-even point in its trading activities, this activity will provide liquidity in the market without creating over- or underpricing. This kind of program

${ }^{183}$ E.g., Ian Sherr, et al., Dell Makes Case to Go Private in Grim Filing, THE WALL STREET JOURNAL (Updated Mar. 29, 2013), http://online.wsj.com/articles/SB1000142412788732350100457839069226860564 4.

${ }^{184}$ See About SharesPost, supra note 7; Secondary Transactions, supra note 7. 
would be especially helpful to bridge any liquidity gap for small investors, like stock compensated employees, who simply need the cash.

In sum, companies listing on the AIM are different from their premier exchange counterparts based on the lack of substantial change in ownership, control, and leverage. However, as AIM companies grow, they mature. For those few companies that achieve premier public company status, including possibly graduating to the Main Market, the AIM provides a gradual on-ramp. For the many companies that will never list on a premier exchange, the AIM provides a structured liquidity market for shareholders, allowing them to more confidently trade their stocks.

\section{CONCLUDING THOUGHTS AND RECOMMENDATIONS}

The AIM is an experiment in light regulation. It tailors regulation to small companies while trying to maintain the quality needed for an exchange to operate. The empirical literature identifies both positive and negative aspects of the AIM. While AIM companies underperform those on premier exchanges, the AIM has helped a significant number of companies raise capital and grow. In particular, the AIM bridges the gap for companies between a premier exchange listing and staying private. Regulators and academics in the U.S. should strongly consider the example of the AIM and the possible benefit an AIM-type market could provide to companies and shareholders in the U.S.

Further study and analysis is required to render a final verdict on the success of the AIM and light exchange regulation. The literature highlights several areas for further study and analysis. First, further study is required to compare AIM companies with their private counterparts. This study should focus on survival, likelihood of ultimate public listing on a premier exchange, and value to shareholders as a structured liquidity market. Second, further study should be conducted to compare the institutional ownership rate on the AIM with that of other exchanges. Third, further study is needed to compare the concentration of ownership of companies on the AIM with those on premier exchanges. Fourth, further study is needed into the rate of fraud on the AIM as compared to other companies. Fifth, and finally, further study is required to determine the connection between raising funds on the AIM, retail investor ownership, and poor market performance. 


\section{APPENDIX 1: BIBLIOGRAPHY OF EMPIRICAL STUDIES ABOUT THE AIM}

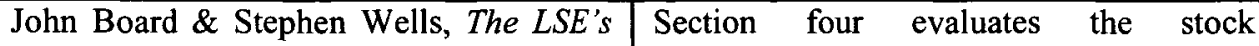
AIM Market: Effect on Returns and Trading of Canadian Stocks, in 5 CANADA STEPS UP 173 (Task Force to Modernize Sec. Legislation in Can. ed., 2006).

Alessandra Colombelli, Entrepreneurial Dimensions of the Growth of Small Companies 10, 12-13 (Università Degli Studi Di Torino, Dipartimento di Economia e Statistica "Cognetti de Martiis", Working Paper No. 2/2009, 2009), available performance of companies that switch between the AIM and the Main Market in an effort to compare stock performance on the two markets.

This study evaluates six years of pre- and post-IPO performance of 665 companies going public on the AIM between 1995 and 2006 and correlates performance with firm characteristics at the time of the IPO. http://www.unito.it/unitoWAR/ShowBinar y/FSRepo/D031/Allegati/WP2009Dip_L\& B/2 WP Momigliano.pdf.

Susanne Espenlaub, et al., Is AIM a Casino? A Study of the Survival of New Listings on the UK Alternative Investment Market (AIM) 13-14 (unpublished manuscript) (on file with the Manchester Business School Manchester Accounting \& Finance Group).

This study evaluates the short-term failure of 641 companies with an IPO on the AIM from 2000 to 2004, and correlates the long-term survival rate of 316 companies with company characteristics. 


\begin{tabular}{|c|c|}
\hline $\begin{array}{l}\text { Joseph Gerakos, et al., Post-listing } \\
\text { Performance and Private Sector } \\
\text { Regulation: The Experience of London's } \\
\text { Alternative Investment Market, 56 J. ACCT. } \\
\text { \& Econ. } 189 \text { (2013); see also Joseph } \\
\text { Gerakos et al., Listing Choices and Self- } \\
\text { Regulation: The Experience of the AIM } \\
\text { (The Univ. of Chi. Booth Sch. of Bus., } \\
\text { Working Paper No. 11-04, 2011), } \\
\text { available } \\
\text { http://ssrn.com/abstract=1739137. }\end{array}$ & $\begin{array}{l}\text { This study compares the stock } \\
\text { performance companies that listed on the } \\
\text { AIM between } 1995 \text { with those that listed } \\
\text { on the Main market of the London Stock } \\
\text { Exchange, the NASDAQ, or the OTC } \\
\text { Bulletin Board, when it was regulated by } \\
\text { the SEC. Out of their original pool of } 1601 \\
\text { AIM companies and } 2406 \text { premier } \\
\text { exchange companies, the authors were } \\
\text { able to match } 1241 \text { AIM companies with a } \\
\text { benchmark counterpart on one of the } \\
\text { premier exchanges. The authors required } \\
\text { that matched firms have a market value of } \\
\text { listing within } \$ 25 \text { million and a listing date } \\
\text { within one year. In addition to providing } \\
\text { descriptive statistics for each exchange, } \\
\text { this study uses multivariate analysis to } \\
\text { compare the exchanges using several } \\
\text { performance measures and identifies } \\
\text { several AIM firm and nomad } \\
\text { characteristics that are associated with } \\
\text { better or worse performance. This study is } \\
\text { more comprehensive than most and } \\
\text { provides expansive comparison of the } \\
\text { AIM with other exchanges. Finally, this } \\
\text { study appears to be the published version } \\
\text { of a working paper by the same authors } \\
\text { titled Listing Choices and Self-Regulation: } \\
\text { The Experience of the AIM. }\end{array}$ \\
\hline $\begin{array}{l}\text { Hafiz Hoque \& Meziane Lasfer, } \\
\text { Directors' Dealing and Post-IPO } \\
\text { Performance, EUR. J. FN. (forthcoming). }\end{array}$ & $\begin{array}{l}\text { This study combines director trading } \\
\text { information with IPO and company } \\
\text { performance data for companies listed on } \\
\text { one of the London Stock Exchange } \\
\text { markets between } 1999 \text { and } 2006 \text {. The } \\
\text { authors categorized the companies based } \\
\text { on their net purchase ratio-purchases less } \\
\text { sells all over total trades-and found } 190 \\
(35 \%) \text { IPOs with net selling by directors } \\
\text { and } 353(65 \%) \text { with net buying. Finally, } \\
\text { the authors analyzed the association } \\
\text { between director's trading activity and } \\
\text { company performance. }\end{array}$ \\
\hline $\begin{array}{l}\text { Arif Khurshed, et al., The Operating and } \\
\text { SharePrice Performance of Initial Public } \\
\text { Offerings: The UK Experience } 9 \\
\text { (unpublished manuscript) (on file with } \\
\text { author). }\end{array}$ & $\begin{array}{l}\text { This study compares four years of post- } \\
\text { IPO performance for } 195 \text { companies that } \\
\text { listed on the AIM with } 216 \text { companies that } \\
\text { listed on the Main Market from } 1995 \\
\text { through } 1999 \text {. }\end{array}$ \\
\hline
\end{tabular}




\begin{tabular}{|c|c|}
\hline $\begin{array}{l}\text { CHRIS MALLIN \& KEAN OW-YONG, INST. } \\
\text { OF CHARTERED ACCOUNTANTS OF SCOT., } \\
\text { CORPORATE GOVERNANCE IN } \\
\text { ALTERNATIVE INVESTMENT MARKET } \\
\text { (AIM) COMPANIES (2008); see also Chris } \\
\text { Mallin \& Kean Ow-Yong, Corporate } \\
\text { Governance in Alternative Investment } \\
\text { Market (AIM) Companies: Determinants } \\
\text { of Corporate Governance Disclosure (Jan. } \\
\text { 12, 2009) (unpublished manuscript), } \\
\text { available } \\
\text { http://ssrn.com/abstract=1326627. }\end{array}$ & $\begin{array}{l}\text { This study evaluates voluntary corporate- } \\
\text { governance-standard-compliance } \\
\text { disclosure of } 300 \text { AIM companies listed on } \\
\text { the AIM before June 2006. The authors } \\
\text { scored each company based on disclosure } \\
\text { of compliance twenty-three best practices } \\
\text { from the Quoted Companies Alliance } \\
\text { (QCA) Guidelines on Corporate } \\
\text { Governance for AIM Companies, which is } \\
\text { based on the UK's Combined Code. The } \\
\text { authors also conducted extensive } \\
\text { interviews with AIM companies, investors, } \\
\text { nomads, and brokers. }\end{array}$ \\
\hline $\begin{array}{l}\text { Chris Mallin \& Kean Ow-Yong, Factors } \\
\text { Influencing Corporate Governance } \\
\text { Disclosures: Evidence from the Alternative } \\
\text { Investment Market (AIM) Companies in } \\
\text { the UK, } 18 \text { EUR. J. FIN. } 515 \text { (2012). }\end{array}$ & $\begin{array}{l}\text { This study evaluates the disclosure of } \\
\text { corporate-governance compliance in } 300 \\
\text { AIM corporate annual reports released for } \\
\text { financial years ending in } 2005 \text { and } 2006 \\
\text { and correlate disclosure with company } \\
\text { characteristics including percent of } \\
\text { institutional ownership, percent of } \\
\text { managerial ownership, board size, board } \\
\text { independence, Nomads that are also } \\
\text { brokers, companies formerly listed on the } \\
\text { Main Market, companies that are shells } \\
\text { without revenue turnover, company size, } \\
\text { and gearing. }\end{array}$ \\
\hline $\begin{array}{l}\text { Sepideh Parsa \& Reza Kouhy, Social } \\
\text { Reporting by Companies Listed on the } \\
\text { Alternative Investment Market, } 79 \mathrm{~J} \text {. Bus. } \\
\text { ETHICs } 345 \text { (2008). }\end{array}$ & $\begin{array}{l}\text { This study examines eighteen categories of } \\
\text { social information disclosed by } 100 \\
\text { companies listed on the AIM from } 2001 \\
\text { through } 2003 \text { and correlates disclosure } \\
\text { with company age, industry, size, and } \\
\text { financial gearing. }\end{array}$ \\
\hline $\begin{array}{l}\text { Valérie Revest \& Alessandro Sapio, Does } \\
\text { the Alternative Investment Market Nurture } \\
\text { Firm Growth? A Comparison Between } \\
\text { Listed and Private Companies, 22 INDUS. } \\
\text { \& CORP. CHANGE } 953 \text { (2013), available at } \\
\text { http://icc.oxfordjournals.org/content/22/4/ } \\
\text { 953.full.pdf+html. }\end{array}$ & $\begin{array}{l}\text { This study compares the productivity of } \\
\text { companies listed on the AIM between } \\
1997 \text { and } 2008 \text { with their private } \\
\text { counterparts. The authors matched limited } \\
\text { liability manufacturing firms incorporated } \\
\text { in the UK with private companies based } \\
\text { on age, size, and industry sector. Using } \\
\text { employee productivity, operating revenue, } \\
\text { and total assets, the authors compared the } \\
\text { growth of the matched companies. }\end{array}$ \\
\hline
\end{tabular}




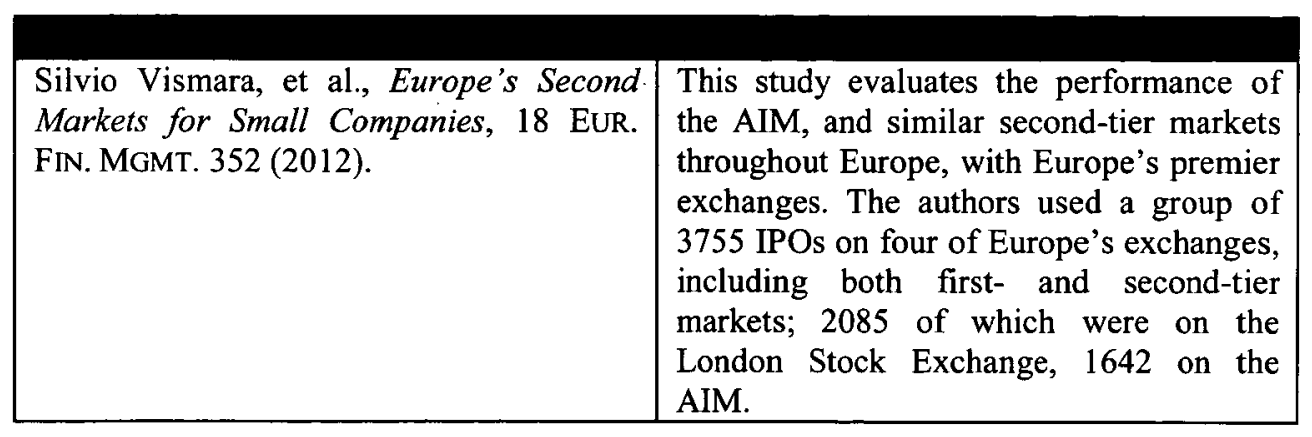

APPENDIX 2: THE EMPIRICAL LANDSCAPE ${ }^{185}$

\begin{tabular}{|l|l|l|}
\hline \multicolumn{2}{|c|}{ A. Associations Between AIM vs. Non-AIM and Book Performance ${ }^{186}$} \\
\hline $\begin{array}{l}\text { AIM listing instead of Main } \\
\text { Market }\end{array}$ & {$[-]^{187}$} & Asset Turnover at IPO \\
\hline $\begin{array}{l}\text { AIM listing instead of Main } \\
\text { Market }\end{array}$ & $\ldots-^{188}$ & $\begin{array}{l}\text { Capital Expenditures Over } \\
\text { Total Assets at IPO }\end{array}$ \\
\hline $\begin{array}{l}\text { AIM listing instead of Main } \\
\text { Market }\end{array}$ & $\ldots-1^{189}$ & $\begin{array}{l}\text { Cash Flow Return on Assets at } \\
\text { IPO }\end{array}$ \\
\hline $\begin{array}{l}\text { AIM listing instead of Main } \\
\text { Market }\end{array}$ & {$[-]^{190}$} & Leverage at IPO \\
\hline $\begin{array}{l}\text { AIM listing instead of Main } \\
\text { Market }\end{array}$ & $\ldots-1^{191}$ & Return on Assets at IPO \\
\hline $\begin{array}{l}\text { AIM listing instead of Main } \\
\text { Market }\end{array}$ & $--^{192}$ & Return on Equity at IPO \\
\hline $\begin{array}{l}\text { AIM listing instead of Main } \\
\text { Market }\end{array}$ & $-\ldots{ }^{193}$ & Return on Sales at IPO \\
\hline
\end{tabular}

\footnotetext{
${ }^{185}$ See supra Part III.B for a description of this chart.

${ }^{186}$ Unless expressly stated, as it is in this case (AIM vs. Non-AIM), the associations are between variables measuring the AIM and its companies. The AIM vs. Non-AIM associations identify differences in dependent variables correlated with listing on the AIM instead of another option. This section, for example, lists all associations between listing on the AIM and book performance measures, such as asset turnover or capital expenditures over total assets.

${ }^{187}$ Khurshed et al., supra note 38 , at 26 tbl.3.

${ }^{188}$ Id.

${ }^{189} \mathrm{Id}$.

${ }^{190} \mathrm{Id}$

${ }^{191}$ Id.

${ }^{192}$ Id.

${ }^{193}$ Id.
} 


\begin{tabular}{|c|c|c|}
\hline $\begin{array}{l}\text { AIM listing instead of Main } \\
\text { Market }\end{array}$ & $--^{194}$ & $\begin{array}{l}\text { Taxes, defined as taxes over } \\
\text { pretax earnings, at IPO }\end{array}$ \\
\hline $\begin{array}{l}\text { AIM listing instead of staying } \\
\text { private }\end{array}$ & {$[+]^{195}$} & Asset Growth \\
\hline $\begin{array}{l}\text { AIM listing instead of staying } \\
\text { private }\end{array}$ & {$[+]^{196}$} & Operational Revenues \\
\hline $\begin{array}{l}\text { AIM listing instead of staying } \\
\text { private }\end{array}$ & $--^{197}$ & $\begin{array}{l}\text { Productivity, defined as added } \\
\text { value over employees }\end{array}$ \\
\hline \multicolumn{3}{|c|}{ B. Associations Between AIM vs. Non-AIM and Company Characteristics } \\
\hline $\begin{array}{l}\text { AIM listing instead of Main } \\
\text { Market }\end{array}$ & $\ldots .-198$ & Age at IPO \\
\hline $\begin{array}{l}\text { AIM listing instead of Main } \\
\text { Market }\end{array}$ & $\ldots .199$ & Assets at IPO \\
\hline $\begin{array}{l}\text { AIM listing instead of Main } \\
\text { Market }\end{array}$ & $--^{200}$ & Number of employees at IPO \\
\hline $\begin{array}{l}\text { AIM listing instead of Main } \\
\text { Market }\end{array}$ & $\ldots 201$ & Sales at IPO \\
\hline $\begin{array}{l}\text { AIM listing instead of } \\
\text { NASDAQ, Main Market, or } \\
\text { OTC Bulletin Board }\end{array}$ & ++202 & Discretionary accruals \\
\hline $\begin{array}{l}\text { AIM listing instead of } \\
\text { NASDAQ, Main Market, or } \\
\text { OTC Bulletin Board }\end{array}$ & $-\ldots 203$ & $\begin{array}{l}\text { Discretionary accruals change } \\
\text { after IPO }\end{array}$ \\
\hline $\begin{array}{l}\text { AIM listing instead of } \\
\text { NASDAQ, Main Market, or } \\
\text { OTC Bulletin Board }\end{array}$ & $t^{204}$ & $\begin{array}{l}\text { Discretionary accruals change } \\
\text { from before to after IPO }\end{array}$ \\
\hline $\begin{array}{l}\text { AIM listing instead of } \\
\text { NASDAQ, Main Market, or } \\
\text { OTC Bulletin Board }\end{array}$ & $\ldots 205$ & $\begin{array}{l}\text { Discretionary accruals reversal } \\
\text { in year after IPO }\end{array}$ \\
\hline
\end{tabular}

${ }^{194}$ Id.

${ }^{195}$ Revest \& Sapio, supra note 51, at 25 tbl.A3 \& 27 tbl.A4 (some models indicate a higher levels of significance).

${ }_{196}$ Id.

${ }^{197}$ Id.

${ }^{198}$ Khurshed et al., supra note 38 , at 26 tbl.3.

${ }^{199} \mathrm{Id}$.

${ }^{200} \mathrm{Id}$.

${ }^{201} \mathrm{Id}$.

${ }^{202}$ Gerakos et al., Post-listing Performance, supra note 17, at 208 tbl.9.

${ }^{203}$ Id .

${ }^{204} \mathrm{Id}$.

${ }^{205} \mathrm{Id}$. 


\begin{tabular}{|c|c|c|}
\hline $\begin{array}{l}\text { AIM listing instead of staying } \\
\text { private }\end{array}$ & ++206 & Number of employees \\
\hline \multicolumn{3}{|c|}{ C. Associations Between AIM vs. Non-AIM and IPO Characteristics } \\
\hline $\begin{array}{l}\text { AIM listing instead of Main } \\
\text { Market }\end{array}$ & $\ldots-^{207}$ & $\begin{array}{l}\text { Equity percentage issued at } \\
\text { IPO }\end{array}$ \\
\hline $\begin{array}{l}\text { AIM listing instead of Main } \\
\text { Market }\end{array}$ & $-\ldots 208$ & Market Capitalization \\
\hline $\begin{array}{l}\text { AIM listing instead of Main } \\
\text { Market }\end{array}$ & $\ldots .209$ & Offer Size \\
\hline \multicolumn{3}{|c|}{ D. Associations Between AIM vs. Non-AIM and Market Liquidity } \\
\hline $\begin{array}{l}\text { AIM listing instead of } \\
\text { NASDAQ, Main Market, OTC } \\
\text { Bulletin Board, or OTC Pink } \\
\text { Sheets }\end{array}$ & $+++^{210}$ & Bid-Ask Spread \\
\hline $\begin{array}{l}\text { AIM listing instead of } \\
\text { NASDAQ, Main Market, OTC } \\
\text { Bulletin Board, or OTC Pink } \\
\text { Sheets }\end{array}$ & $++t^{211}$ & Trading days with zero returns \\
\hline \multicolumn{3}{|c|}{ E. Associations Between AIM vs. Non-AIM and Market Performance } \\
\hline $\begin{array}{l}\text { AIM listing instead of FTSE } \\
\text { Euromid Index }\end{array}$ & $\ldots$ & $\begin{array}{l}\text { Thirty-six-month buy-and-hold } \\
\text { returns }\end{array}$ \\
\hline $\begin{array}{l}\text { AIM listing instead of FTSE } \\
\text { Euromid Index }\end{array}$ & $\ldots .213$ & $\begin{array}{l}\text { Sixty-month buy-and-hold } \\
\text { returns }\end{array}$ \\
\hline $\begin{array}{l}\text { AIM listing instead of Main } \\
\text { Market }\end{array}$ & $\ldots .214$ & $\begin{array}{l}\text { One-month buy-and-hold } \\
\text { return, compared to market } \\
\text { average }\end{array}$ \\
\hline
\end{tabular}

${ }^{206}$ Revest \& Sapio, supra note 51, at 25 tbl.A3 \& \& 27 tbl.A4.

${ }^{207}$ Khurshed et al., supra note 38 , at 26 tbl.3.

${ }^{208}$ Id.

${ }^{209} \mathrm{Id}$.

${ }^{210}$ Gerakos et al., Listing Choices, supra note 34 , at 56-57 tbls.8-9 \& 60-61

tbls.12-13.

211 Id.

${ }^{212}$ Vismara et al., supra note 54 , at $368-69$, tbl.5.

${ }^{213} \mathrm{Id}$.

${ }^{214}$ Hoque \& Lasfer, supra note 35 , at 10 tbl.2. 


\begin{tabular}{|l|c|l|}
\hline \multicolumn{2}{|l|}{} \\
$\begin{array}{l}\text { AIM listing instead of Main } \\
\text { Market }\end{array}$ & {$[+]^{215}$} & $\begin{array}{l}\text { Twelve-month buy-and-hold } \\
\text { return, compared to market } \\
\text { average }\end{array}$ \\
\hline $\begin{array}{l}\text { AIM listing instead of Main } \\
\text { Market }\end{array}$ & {$[-]^{216}$} & $\begin{array}{l}\text { Twenty-four month buy-and- } \\
\text { hold return, compared to } \\
\text { market average }\end{array}$ \\
\hline $\begin{array}{l}\text { AIM listing instead of Main } \\
\text { Market }\end{array}$ & {$[-]^{217}$} & $\begin{array}{l}\text { Thirty-six-month buy-and-hold } \\
\text { return, compared to market } \\
\text { average }\end{array}$ \\
\hline $\begin{array}{l}\text { AIM listing instead of Main } \\
\text { Market }\end{array}$ & {$[+]^{218}$} & $\begin{array}{l}\text { Six-month buy-and-hold return, } \\
\text { compared to market average }\end{array}$ \\
\hline $\begin{array}{l}\text { AIM listing instead of Main } \\
\text { Market }\end{array}$ & $--^{219}$ & $\begin{array}{l}\text { Month nineteen to thirty-six } \\
\text { buy-and-hold return, compared } \\
\text { to market average }\end{array}$ \\
\hline $\begin{array}{l}\text { AIM listing instead of Main } \\
\text { Market }\end{array}$ & {$[+]^{220}$} & $\begin{array}{l}\text { Month two to eighteen buy- } \\
\text { and-hold return, compared to } \\
\text { market average }\end{array}$ \\
\hline $\begin{array}{l}\text { AIM listing instead of Main } \\
\text { Market, where there is net } \\
\text { buying by insiders for the first } \\
\text { thirty-six months }\end{array}$ & {$[-]^{221}$} & $\begin{array}{l}\text { One-month buy-and-hold } \\
\text { return, compared to market } \\
\text { average }\end{array}$ \\
\hline $\begin{array}{l}\text { AIM listing instead of Main } \\
\text { Market, where there is net } \\
\text { buying by insiders for the first } \\
\text { thirty-six months }\end{array}$ & {$[+]^{223}$} & $\begin{array}{l}\text { hold return, compared to } \\
\text { market average }\end{array}$ \\
\hline $\begin{array}{l}\text { AIM listing instead of Main } \\
\text { Market, where there is net } \\
\text { thirty-six months }\end{array}$ & {$[+]^{222}$} & $\begin{array}{l}\text { Twelve-month buy-and-hold } \\
\text { return, compared to market } \\
\text { average }\end{array}$ \\
\hline $\begin{array}{l}\text { AIM listing instead of Main } \\
\text { buying by insiders for the first } \\
\text { thirty-six months }\end{array}$ & & $\begin{array}{l}\text { Thirty-six-month buy-and-hold } \\
\text { return, compared to market } \\
\text { average }\end{array}$ \\
\hline
\end{tabular}




\begin{tabular}{|c|c|c|}
\hline $\begin{array}{l}\text { AIM listing instead of Main } \\
\text { Market, where there is net } \\
\text { buying by insiders for the first } \\
\text { thirty-six months }\end{array}$ & {$[+]^{225}$} & $\begin{array}{l}\text { Six-month buy-and-hold return, } \\
\text { compared to market average }\end{array}$ \\
\hline $\begin{array}{l}\text { AIM listing instead of Main } \\
\text { Market, where there is net } \\
\text { buying by insiders for the first } \\
\text { thirty-six months }\end{array}$ & {$[-]^{226}$} & $\begin{array}{l}\text { Month nineteen to thirty-six } \\
\text { buy-and-hold return, compared } \\
\text { to market average }\end{array}$ \\
\hline $\begin{array}{l}\text { AIM listing instead of Main } \\
\text { Market, where there is net } \\
\text { buying by insiders for the first } \\
\text { thirty-six months }\end{array}$ & {$[+]^{227}$} & $\begin{array}{l}\text { Month two to eighteen buy- } \\
\text { and-hold return, compared to } \\
\text { market average }\end{array}$ \\
\hline $\begin{array}{l}\text { AIM listing instead of Main } \\
\text { Market, where there is net } \\
\text { selling by insiders for the first } \\
\text { thirty-six months }\end{array}$ & $\ldots .228$ & $\begin{array}{l}\text { One-month buy-and-hold } \\
\text { return, compared to market } \\
\text { average }\end{array}$ \\
\hline $\begin{array}{l}\text { AIM listing instead of Main } \\
\text { Market, where there is net } \\
\text { selling by insiders for the first } \\
\text { thirty-six months }\end{array}$ & +229 & $\begin{array}{l}\text { Twelve-month buy-and-hold } \\
\text { return, compared to market } \\
\text { average }\end{array}$ \\
\hline $\begin{array}{l}\text { AIM listing instead of Main } \\
\text { Market, where there is net } \\
\text { selling by insiders for the first } \\
\text { thirty-six months }\end{array}$ & $t^{230}$ & $\begin{array}{l}\text { Twenty-four-month buy-and- } \\
\text { hold return, compared to } \\
\text { market average }\end{array}$ \\
\hline $\begin{array}{l}\text { AIM listing instead of Main } \\
\text { Market, where there is net } \\
\text { selling by insiders for the first } \\
\text { thirty-six months }\end{array}$ & +231 & $\begin{array}{l}\text { Thirty-six-month buy-and-hold } \\
\text { return, compared to market } \\
\text { average }\end{array}$ \\
\hline $\begin{array}{l}\text { AIM listing instead of Main } \\
\text { Market, where there is net } \\
\text { selling by insiders for the first } \\
\text { thirty-six months }\end{array}$ & {$[+]^{232}$} & $\begin{array}{l}\text { Six-month buy-and-hold return, } \\
\text { compared to market average }\end{array}$ \\
\hline $\begin{array}{l}\text { AIM listing instead of Main } \\
\text { Market, where there is net } \\
\text { selling by insiders for the first } \\
\text { thirty-six months }\end{array}$ & {$[-]^{233}$} & $\begin{array}{l}\text { Month nineteen to thirty-six } \\
\text { buy-and-hold return, compared } \\
\text { to market average }\end{array}$ \\
\hline
\end{tabular}




\begin{tabular}{|c|c|c|}
\hline $\begin{array}{l}\text { AIM listing instead of Main } \\
\text { Market, where there is net } \\
\text { selling by insiders for the first } \\
\text { thirty-six months }\end{array}$ & $+t^{234}$ & $\begin{array}{l}\text { Month two to eighteen buy- } \\
\text { and-hold return, compared to } \\
\text { market average }\end{array}$ \\
\hline $\begin{array}{l}\text { AIM listing instead of Main } \\
\text { Market, where there is no } \\
\text { trading by insiders for the first } \\
\text { thirty-six months }\end{array}$ & $\ldots .235$ & $\begin{array}{l}\text { One-month buy-and-hold } \\
\text { return, compared to market } \\
\text { average }\end{array}$ \\
\hline $\begin{array}{l}\text { AIM listing instead of Main } \\
\text { Market, where there is no } \\
\text { trading by insiders for the first } \\
\text { thirty-six months }\end{array}$ & {$[-]^{236}$} & $\begin{array}{l}\text { Twelve-month buy-and-hold } \\
\text { return, compared to market } \\
\text { average }\end{array}$ \\
\hline $\begin{array}{l}\text { AIM listing instead of Main } \\
\text { Market, where there is no } \\
\text { trading by insiders for the first } \\
\text { thirty-six months }\end{array}$ & {$[-]^{237}$} & $\begin{array}{l}\text { Twenty-four-month buy-and- } \\
\text { hold return, compared to } \\
\text { market average }\end{array}$ \\
\hline $\begin{array}{l}\text { AIM listing instead of Main } \\
\text { Market, where there is no } \\
\text { trading by insiders for the first } \\
\text { thirty-six months }\end{array}$ & {$[-]^{238}$} & $\begin{array}{l}\text { Thirty-six-month buy-and-hold } \\
\text { return, compared to market } \\
\text { average }\end{array}$ \\
\hline $\begin{array}{l}\text { AIM listing instead of Main } \\
\text { Market, where there is no } \\
\text { trading by insiders for the first } \\
\text { thirty-six months }\end{array}$ & {$[-]^{239}$} & $\begin{array}{l}\text { Six-month buy-and-hold return, } \\
\text { compared to market average }\end{array}$ \\
\hline $\begin{array}{l}\text { AIM listing instead of Main } \\
\text { Market, where there is no } \\
\text { trading by insiders for the first } \\
\text { thirty-six months }\end{array}$ & {$[-]^{240}$} & $\begin{array}{l}\text { Month nineteen to thirty-six } \\
\text { buy-and-hold return, compared } \\
\text { to market average }\end{array}$ \\
\hline $\begin{array}{l}\text { AIM listing instead of Main } \\
\text { Market, where there is no } \\
\text { trading by insiders for the first } \\
\text { thirty-six months }\end{array}$ & {$[+]^{241}$} & $\begin{array}{l}\text { Month two to eighteen buy- } \\
\text { and-hold return, compared to } \\
\text { market average }\end{array}$ \\
\hline $\begin{array}{l}\text { AIM listing instead of } \\
\text { NASDAQ, Main Market, or } \\
\text { OTC Bulletin Board }\end{array}$ & $\ldots 242$ & $\begin{array}{l}\text { Twelve-month buy-and-hold } \\
\text { return }\end{array}$ \\
\hline
\end{tabular}

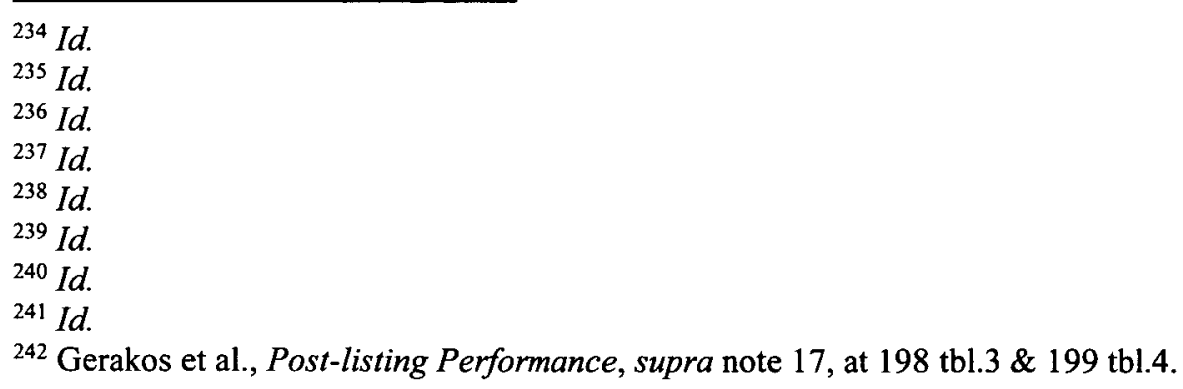




\begin{tabular}{|c|c|c|}
\hline $\begin{array}{l}\text { AIM listing instead of } \\
\text { NASDAQ, Main Market, or } \\
\text { OTC Bulletin Board }\end{array}$ & $--^{243}$ & $\begin{array}{l}\text { Twelve-month buy-and-hold } \\
\text { return over } 200 \%\end{array}$ \\
\hline $\begin{array}{l}\text { AIM listing instead of } \\
\text { NASDAQ, Main Market, or } \\
\text { OTC Bulletin Board }\end{array}$ & -.244 & $\begin{array}{l}\text { Twelve-month buy-and-hold } \\
\text { returns for firms that have an } \\
\text { increase in discretionary } \\
\text { accruals }\end{array}$ \\
\hline $\begin{array}{l}\text { AIM listing instead of } \\
\text { NASDAQ, Main Market, or } \\
\text { OTC Bulletin Board }\end{array}$ & $\ldots 245$ & $\begin{array}{l}\text { Twelve-month buy-and-hold } \\
\text { returns for firms that raise } \\
\text { capital }\end{array}$ \\
\hline $\begin{array}{l}\text { AIM listing instead of } \\
\text { NASDAQ, Main Market, or } \\
\text { OTC Bulletin Board }\end{array}$ & $\ldots-^{246}$ & $\begin{array}{l}\text { Twelve-month buy-and-hold } \\
\text { returns over } 100 \%\end{array}$ \\
\hline $\begin{array}{l}\text { AIM listing instead of } \\
\text { NASDAQ, Main Market, or } \\
\text { OTC Bulletin Board }\end{array}$ & $\ldots 247$ & $\begin{array}{l}\text { Eighteen-month buy-and-hold } \\
\text { return }\end{array}$ \\
\hline $\begin{array}{l}\text { AIM listing instead of } \\
\text { NASDAQ, Main Market, or } \\
\text { OTC Bulletin Board } \\
\end{array}$ & $--^{248}$ & $\begin{array}{l}\text { Eighteen-month buy-and-hold } \\
\text { return over } 200 \%\end{array}$ \\
\hline $\begin{array}{l}\text { AIM listing instead of } \\
\text { NASDAQ, Main Market, or } \\
\text { OTC Bulletin Board }\end{array}$ & $\ldots 249$ & $\begin{array}{l}\text { Eighteen-month buy-and-hold } \\
\text { returns before and after AIM } \\
\text { reforms of } 2007\end{array}$ \\
\hline $\begin{array}{l}\text { AIM listing instead of } \\
\text { NASDAQ, Main Market, or } \\
\text { OTC Bulletin Board }\end{array}$ & -250 & $\begin{array}{l}\text { Eighteen-month buy-and-hold } \\
\text { returns for firms that have an } \\
\text { increase in discretionary } \\
\text { accruals }\end{array}$ \\
\hline $\begin{array}{l}\text { AIM listing instead of } \\
\text { NASDAQ, Main Market, or } \\
\text { OTC Bulletin Board }\end{array}$ & -251 & $\begin{array}{l}\text { Eighteen-month buy-and-hold } \\
\text { returns for firms that raise } \\
\text { capital }\end{array}$ \\
\hline $\begin{array}{l}\text { AIM listing instead of } \\
\text { NASDAQ, Main Market, or } \\
\text { OTC Bulletin Board }\end{array}$ & $--^{252}$ & $\begin{array}{l}\text { Eighteen-month buy-and-hold } \\
\text { returns over } 100 \%\end{array}$ \\
\hline $\begin{array}{l}\text { AIM listing instead of } \\
\text { NASDAQ, Main Market, or } \\
\text { OTC Bulletin Board } \\
\end{array}$ & $\ldots--^{253}$ & $\begin{array}{l}\text { Twenty-four-month buy-and- } \\
\text { hold return }\end{array}$ \\
\hline
\end{tabular}

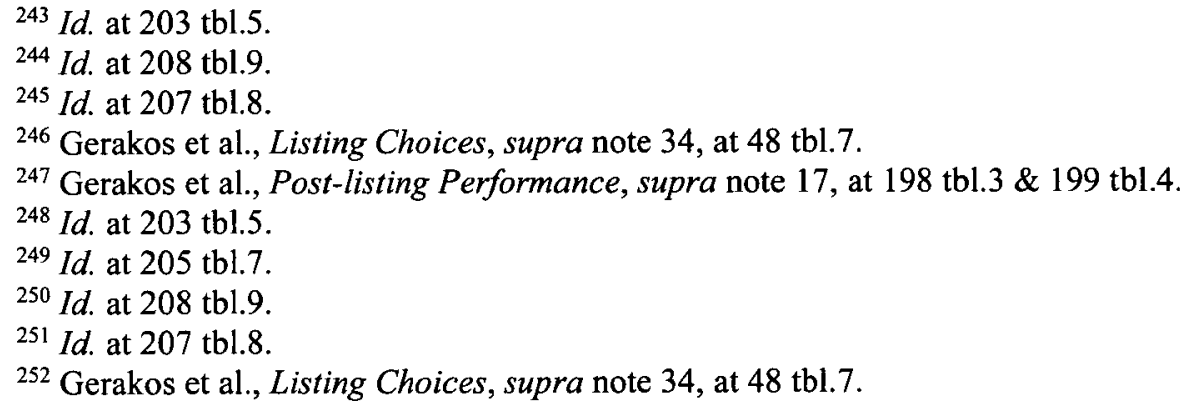




\begin{tabular}{|c|c|c|}
\hline $\begin{array}{l}\text { AIM listing instead of } \\
\text { NASDAQ, Main Market, or } \\
\text { OTC Bulletin Board }\end{array}$ & -.254 & $\begin{array}{l}\text { Twenty-four-month buy-and- } \\
\text { hold returns for firms that have } \\
\text { an increase in discretionary } \\
\text { accruals }\end{array}$ \\
\hline $\begin{array}{l}\text { AIM listing instead of } \\
\text { NASDAQ, Main Market, or } \\
\text { OTC Bulletin Board }\end{array}$ & -255 & $\begin{array}{l}\text { Twenty-four-month buy-and- } \\
\text { hold returns for firms that raise } \\
\text { capital }\end{array}$ \\
\hline $\begin{array}{l}\text { AIM listing instead of } \\
\text { NASDAQ, Main Market, or } \\
\text { OTC Bulletin Board }\end{array}$ & $-\ldots 256$ & $\begin{array}{l}\text { Twenty-four-month buy-and- } \\
\text { hold returns over } 200 \%\end{array}$ \\
\hline $\begin{array}{l}\text { AIM listing instead of } \\
\text { NASDAQ, Main Market, or } \\
\text { OTC Bulletin Board }\end{array}$ & $--^{257}$ & $\begin{array}{l}\text { Thirty-six-month buy-and-hold } \\
\text { return }\end{array}$ \\
\hline $\begin{array}{l}\text { AIM listing instead of OTC } \\
\text { Pink Sheets }\end{array}$ & {$[-]^{258}$} & $\begin{array}{l}\text { Twelve-month buy-and-hold } \\
\text { returns }\end{array}$ \\
\hline $\begin{array}{l}\text { AIM listing instead of OTC } \\
\text { Pink Sheets }\end{array}$ & -259 & $\begin{array}{l}\text { Eighteen-month buy-and-hold } \\
\text { returns }\end{array}$ \\
\hline $\begin{array}{l}\text { AIM listing instead of OTC } \\
\text { Pink Sheets }\end{array}$ & {$[-]^{260}$} & $\begin{array}{l}\text { Twenty-four-month buy-and- } \\
\text { hold returns }\end{array}$ \\
\hline $\begin{array}{l}\text { OTC Pink Sheets listing } \\
\text { instead of AIM }\end{array}$ & $++t^{261}$ & $\begin{array}{l}\text { Twelve-month buy-and-hold } \\
\text { return }\end{array}$ \\
\hline $\begin{array}{l}\text { OTC Pink Sheets listing } \\
\text { instead of AIM }\end{array}$ & $+^{262}$ & $\begin{array}{l}\text { Eighteen-month buy-and-hold } \\
\text { return }\end{array}$ \\
\hline $\begin{array}{l}\text { OTC Pink Sheets listing } \\
\text { instead of AIM }\end{array}$ & $t^{263}$ & $\begin{array}{l}\text { Twenty-four-month buy-and- } \\
\text { hold return }\end{array}$ \\
\hline \multicolumn{3}{|c|}{ F. Associations Between AIM vs. Non-AIM and Ownership } \\
\hline $\begin{array}{l}\text { AIM listing instead of Main } \\
\text { Market }\end{array}$ & $+++^{264}$ & $\begin{array}{l}\text { Change in ownership } \\
\text { percentage by board } \\
\text { shareholders from pre- to post- } \\
\text { IPO }\end{array}$ \\
\hline
\end{tabular}

${ }^{253}$ Gerakos et al., Post-listing Performance, supra note 17, at 198 tbl.3 \& 199 tbl.4.

${ }^{254}$ Id. at 208 tbl.9.

${ }^{255}$ Id. at 207 tbl.8.

256 Id. at 203 tbl.5.

${ }^{257}$ Id. at 199 tbl.4.

${ }^{258}$ Gerakos et al., Listing Choices, supra note 34, at 53 tbl.12.

${ }^{259} \mathrm{Id}$.

${ }^{260} \mathrm{Id}$.

${ }^{261}$ Gerakos et al., Post-listing Performance, supra note 17, at 205 tbl.7.

${ }^{262} \mathrm{Id}$.

${ }^{263} \mathrm{Id}$.

${ }^{264}$ Khurshed et al., supra note 38, at 27 tbl.4. 


\begin{tabular}{|c|c|c|}
\hline $\begin{array}{l}\text { AIM listing instead of Main } \\
\text { Market }\end{array}$ & +++265 & $\begin{array}{l}\text { Ownership percentage by board } \\
\text { shareholders post-IPO }\end{array}$ \\
\hline $\begin{array}{l}\text { AIM listing instead of Main } \\
\text { Market }\end{array}$ & +++266 & $\begin{array}{l}\text { Ownership percentage by board } \\
\text { shareholders pre-IPO }\end{array}$ \\
\hline $\begin{array}{l}\text { AIM listing instead of Main } \\
\text { Market }\end{array}$ & $\ldots .267$ & $\begin{array}{l}\text { Top four shareholders } \\
\text { ownership percentage change } \\
\text { from pre- to post-IPO }\end{array}$ \\
\hline $\begin{array}{l}\text { AIM listing instead of Main } \\
\text { Market }\end{array}$ & +++268 & $\begin{array}{l}\text { Top four shareholders } \\
\text { ownership percentage post-IPO }\end{array}$ \\
\hline $\begin{array}{l}\text { AIM listing instead of Main } \\
\text { Market }\end{array}$ & {$[+]^{269}$} & $\begin{array}{l}\text { Top four shareholders } \\
\text { ownership percentage pre-IPO }\end{array}$ \\
\hline $\begin{array}{l}\text { AIM listing instead of Main } \\
\text { Market }\end{array}$ & $\ldots 270$ & $\begin{array}{l}\text { Venture capitalist shareholder } \\
\text { ownership percentage change } \\
\text { from pre- to post-IPO }\end{array}$ \\
\hline $\begin{array}{l}\text { AIM listing instead of Main } \\
\text { Market }\end{array}$ & {$[+]^{271}$} & $\begin{array}{l}\text { Venture capitalist shareholder } \\
\text { ownership percentage post-IPO }\end{array}$ \\
\hline $\begin{array}{l}\text { AIM listing instead of Main } \\
\text { Market }\end{array}$ & {$[-]^{272}$} & $\begin{array}{l}\text { Venture capitalist shareholder } \\
\text { ownership percentage pre-IPO }\end{array}$ \\
\hline \multicolumn{3}{|c|}{ G. Associations Between AIM vs. Non-AIM and Company Survival } \\
\hline $\begin{array}{l}\text { AIM listing instead of } \\
\text { NASDAQ, Main Market, or } \\
\text { OTC Bulletin Board }\end{array}$ & $\ldots .273$ & $\begin{array}{l}\text { Good delisting, defined as } \\
\text { positive returns twenty days } \\
\text { prior to delisting }\end{array}$ \\
\hline $\begin{array}{l}\text { AIM listing instead of } \\
\text { NASDAQ, Main Market, or } \\
\text { OTC Bulletin Board }\end{array}$ & $\ldots .274$ & $\begin{array}{l}\text { Good delisting, defined as } \\
\text { positive returns forty days prior } \\
\text { to delisting }\end{array}$ \\
\hline $\begin{array}{l}\text { AIM listing instead of } \\
\text { NASDAQ, Main Market, or } \\
\text { OTC Bulletin Board }\end{array}$ & $\ldots 275$ & $\begin{array}{l}\text { Good delisting, defined as } \\
\text { positive returns sixty days prior } \\
\text { to delisting }\end{array}$ \\
\hline
\end{tabular}

${ }^{265} \mathrm{Id}$.
${ }^{266} \mathrm{Id}$.
${ }^{267} \mathrm{Id}$.
${ }^{268} \mathrm{Id}$.
${ }^{269} \mathrm{Id}$.
${ }^{270} \mathrm{Id}$.
${ }^{271} \mathrm{Id}$.
${ }^{272} \mathrm{Id}$.
${ }^{273} \mathrm{Gerakos}$ et al., Post-listing Performance, supra note 17 , at 203 tbl.5.
${ }^{274} \mathrm{Id}$.




\begin{tabular}{|c|c|c|}
\hline $\begin{array}{l}\text { AIM listing instead of } \\
\text { NASDAQ, Main Market, OTC } \\
\text { Bulletin Board, or OTC Pink } \\
\text { Sheets }\end{array}$ & $++++^{276}$ & Accelerated time to failure \\
\hline \multicolumn{3}{|c|}{ H. Associations Between Auditor Characteristics and Company Characteristics ${ }^{277}$} \\
\hline $\begin{array}{l}\text { Auditor quality, defined as the } \\
\text { company's auditor, is one of } \\
\text { the "big four" }\end{array}$ & $++++^{278}$ & Assets \\
\hline $\begin{array}{l}\text { Auditor quality, defined as the } \\
\text { company's auditor, is one of } \\
\text { the "big four" }\end{array}$ & -279 & $\begin{array}{l}\text { Board quality, defined as } \\
\text { percent of directors holding } \\
\text { shares }\end{array}$ \\
\hline $\begin{array}{l}\text { Auditor quality, defined as the } \\
\text { company's auditor, is one of } \\
\text { the "big four" }\end{array}$ & +++280 & Board quality, defined as size \\
\hline $\begin{array}{l}\text { Auditor quality, defined as the } \\
\text { company's auditor, is one of } \\
\text { the "big four" }\end{array}$ & {$[+]^{281}$} & $\begin{array}{l}\text { Disclosure of corporate } \\
\text { governance standards } \\
\text { compliance }\end{array}$ \\
\hline \multicolumn{3}{|c|}{ I. Associations Between Auditor Characteristics and Market Performance } \\
\hline $\begin{array}{l}\text { Auditor quality, defined as the } \\
\text { company's auditor, is one of } \\
\text { the biggest five international } \\
\text { auditing firms }\end{array}$ & $++t^{282}$ & $\begin{array}{l}\text { Eighteen-month buy-and-hold } \\
\text { returns }\end{array}$ \\
\hline \multicolumn{3}{|c|}{ J. Associations Between Auditor Characteristics and Company Survival } \\
\hline $\begin{array}{l}\text { Auditor quality, defined as the } \\
\text { company's auditor, is one of } \\
\text { the "big four" }\end{array}$ & {$[+]^{283}$} & $\begin{array}{l}\text { Market switching from Main } \\
\text { Market to AIM }\end{array}$ \\
\hline
\end{tabular}

${ }^{276}$ Id. at 204 tbl.6; Gerakos et al., Listing Choices, supra note 34, at 61 tbl.13.

${ }^{277}$ As discussed above, see supra note 186, associations that do not expressly indicate comparison of non-AIM variables include only AIM-related correlations. In this case, for example, the correlations are between characteristics of AIM auditors, such as being one of the big four, and AIM company characteristics, such as the amount of total assets.

${ }^{278}$ MALLIN \& OW-YONG, supra note 41, at 89 tbl.5.5.

${ }^{279}$ Mallin \& Ow-Yong, supra note 44, at 30 tbl.6.

${ }^{280}$ MALLIN \& OW-YONG, supra note 41 , at 89 tbl.5.5.

${ }^{281} \mathrm{Id}$. at 90 tbl.5.6.

282 Gerakos et al., Post-listing Performance, supra note 17, at 210 tbl.10.

${ }^{283}$ MALLIN \& OW-YONG, supra note 41 , at 89 tbl.5.5. 


\begin{tabular}{|c|c|c|}
\hline \multicolumn{3}{|c|}{ K. Associations Between Book Performance and Book Performance } \\
\hline Gearing & +284 & Sales Growth \\
\hline Sales & $\ldots .-285$ & Sales Growth \\
\hline \multicolumn{3}{|c|}{ L. Associations Between Book Performance and Company Characteristics } \\
\hline Assets & $\ldots--^{286}$ & $\begin{array}{l}\text { Board quality, defined as } \\
\text { percent of directors holding } \\
\text { shares }\end{array}$ \\
\hline Assets & +++287 & Board quality, defined as size \\
\hline Assets and any turnover & $++t^{288}$ & $\begin{array}{l}\text { Disclosure of corporate } \\
\text { governance standards } \\
\text { compliance }\end{array}$ \\
\hline Gearing & {$[+]^{289}$} & Assets \\
\hline Gearing & +290 & $\begin{array}{l}\text { Board quality, defined as } \\
\text { percent of directors holding } \\
\text { shares }\end{array}$ \\
\hline Gearing & $-{ }_{-291}^{291}$ & $\begin{array}{l}\text { Board quality, defined as } \\
\text { percent of nonexecutive } \\
\text { directors }\end{array}$ \\
\hline Gearing & {$[-]^{292}$} & Board quality, defined as size \\
\hline Gearing & - 293 & $\begin{array}{l}\text { Disclosure of corporate } \\
\text { governance standards } \\
\text { compliance }\end{array}$ \\
\hline Gearing & +294 & $\begin{array}{l}\text { Disclosure of social } \\
\text { information }\end{array}$ \\
\hline
\end{tabular}

${ }^{284}$ Colombelli, supra note 26 , at 21 tbl.3 \& 22 tbl.4.

${ }^{285} \mathrm{Id}$.

${ }^{286}$ Mallin \& Ow-Yong, supra note 45, at 527 tbl.6.

${ }^{287} \mathrm{Id}$; MALLIN \& OW-YONG, supra note 41, at 89 tbl.5.5.

${ }^{288}$ MALLIN \& OW-YONG, supra note 41, at 90 tbl.5.6; Mallin \& Ow-Yong, supra note 45 , at 527 tbl.7.

${ }^{289}$ MALLIN \& OW-YONG, supra note 41, at 89 tbl.5.5; Mallin \& Ow-Yong, supra note 45 , at 527 tbl. 6 .

${ }^{290}$ Mallin \& Ow-Yong, supra note 45, at 527 tbl.6.

${ }^{291} \mathrm{Id}$.

${ }^{292}$ Id.; MALLIN \& OW-YONG, supra note 41, at 89 tbl.5.5.

${ }^{293}$ MALLIN \& OW-YONG, supra note 41, at 90 tbl.5.6; Mallin \& Ow-Yong, supra note 45 , at 527 tbl.7.

${ }^{294}$ Parsa \& Kouhy, supra note 47, at 356 tbl.X. 


\begin{tabular}{|c|c|c|}
\hline Market Capitalization & {$[+]^{295}$} & $\begin{array}{l}\text { Disclosure of social } \\
\text { information }\end{array}$ \\
\hline Revenue / Turnover & +++296 & $\begin{array}{l}\text { Disclosure of social } \\
\text { information }\end{array}$ \\
\hline \multicolumn{3}{|c|}{ M. Associations Between Book Performance and IPO Characteristics } \\
\hline Market Capitalization & {$[+]^{297}$} & $\begin{array}{l}\text { Initial return, defined as market } \\
\text { capitalization at close of listing } \\
\text { date less IPO proceeds }\end{array}$ \\
\hline \multicolumn{3}{|c|}{ N. Associations Between Book Performance and Company Survival } \\
\hline Assets & {$[+]^{298}$} & $\begin{array}{l}\text { Market switching from Main } \\
\text { Market to AIM }\end{array}$ \\
\hline Gearing & {$[+]^{299}$} & $\begin{array}{l}\text { Market switching from Main } \\
\text { Market to AIM }\end{array}$ \\
\hline Market Capitalization & $--_{-300}$ & $\begin{array}{l}\text { Good delisting, defined as } \\
\text { merger or acquisition }\end{array}$ \\
\hline Market Capitalization & +++301 & Survival time \\
\hline \multicolumn{3}{|c|}{ O. Associations Between CEO Characteristics and Book Performance } \\
\hline CEO quality, defined as age & .302 & Sales Growth \\
\hline $\begin{array}{l}\text { CEO quality, defined as CEO } \\
\text { is also the company founder }\end{array}$ & -303 & Sales Growth \\
\hline $\begin{array}{l}\text { CEO quality, defined as the } \\
\text { CEO has previous experience } \\
\text { on other firms' board of } \\
\text { directors }\end{array}$ & {$[-]^{304}$} & Sales Growth \\
\hline
\end{tabular}

\footnotetext{
${ }^{295}$ Id. at 356 tbl.IX.

${ }^{296}$ Id.

${ }^{297}$ Espenlaub et al., supra note 28, at 38 app. tbl.1.

${ }^{298}$ MALLIN \& OW-YONG, supra note 41, at 89 tbl.5.5; Mallin \& Ow-Yong, supra note 45 , at 527 tbl.6.

${ }^{299}$ MALLIN \& OW-YONG, supra note 41, at 89 tbl.5.5; Mallin \& Ow-Yong, supra note 45 , at 527 tbl.6.

${ }^{300}$ Espenlaub et al., supra note 28 , at 29 tbl.8.

${ }^{301}$ Id. at 30 tbl. 9 \& 31 tbl. 10.

${ }^{302}$ Colombelli, supra note 26 , at 21 tbl. 3 \& 22 tbl.4.

${ }^{303} \mathrm{Id}$.

${ }^{304} \mathrm{Id}$.
} 


\begin{tabular}{|c|c|c|}
\hline $\begin{array}{l}\text { CEO quality, defined as the } \\
\text { CEO received a post-graduate } \\
\text { degree, such as MA, MSc, } \\
\text { MBIM, MRPharm, MBE, or } \\
\text { MBA }\end{array}$ & ++305 & Sales Growth \\
\hline $\begin{array}{l}\text { CEO quality, defined as the } \\
\text { CEO holds a title such as } \mathrm{PhD} \text {, } \\
\mathrm{Dr} \text {, Prof, or OBE as reported in } \\
\text { the IPO prospectus }\end{array}$ & {$[-]^{306}$} & Sales Growth \\
\hline \multicolumn{3}{|c|}{ P. Associations Between Company Characteristics and Book Performance } \\
\hline Age & -307 & Sales Growth \\
\hline $\begin{array}{l}\text { Board quality, defined as at } \\
\text { least one director who received } \\
\text { at least an undergraduate } \\
\text { degree }\end{array}$ & {$[-]^{308}$} & Sales Growth \\
\hline \multicolumn{3}{|c|}{ Q. Associations Between Certain Company Characteristics } \\
\hline Age & - - - 309 & $\begin{array}{l}\text { Disclosure of corporate } \\
\text { governance standards } \\
\text { compliance }\end{array}$ \\
\hline Age & {$[+]^{310}$} & $\begin{array}{l}\text { Disclosure of social } \\
\text { information }\end{array}$ \\
\hline $\begin{array}{l}\text { Board quality, defined as } \\
\text { percent of nonexecutive } \\
\text { directors }\end{array}$ & {$[+]^{311}$} & Assets \\
\hline $\begin{array}{l}\text { Board quality, defined as } \\
\text { percent of nonexecutive } \\
\text { directors }\end{array}$ & $--^{312}$ & $\begin{array}{l}\text { Board quality, defined as } \\
\text { percent of directors holding } \\
\text { shares }\end{array}$ \\
\hline $\begin{array}{l}\text { Board quality, defined as } \\
\text { percent of nonexecutive } \\
\text { directors }\end{array}$ & {$[+]^{313}$} & Board quality, defined as size \\
\hline
\end{tabular}

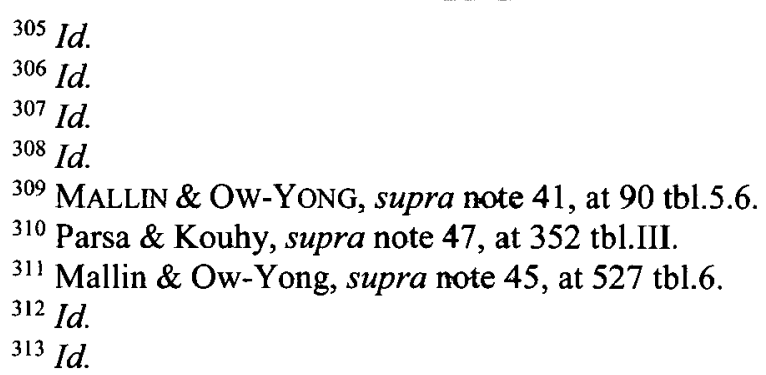




\begin{tabular}{|c|c|c|}
\hline $\begin{array}{l}\text { Board quality, defined as } \\
\text { percent of nonexecutive } \\
\text { directors }\end{array}$ & +++314 & $\begin{array}{l}\text { Disclosure of corporate } \\
\text { governance standards } \\
\text { compliance }\end{array}$ \\
\hline Board quality, defined as size & +++315 & Assets \\
\hline Board quality, defined as size & {$[+]^{316}$} & $\begin{array}{l}\text { Board quality, defined as } \\
\text { percent of nonexecutive } \\
\text { directors }\end{array}$ \\
\hline Board quality, defined as size & +++317 & $\begin{array}{l}\text { Disclosure of corporate } \\
\text { governance standards } \\
\text { compliance }\end{array}$ \\
\hline Employees, number of & {$[+]^{318}$} & $\begin{array}{l}\text { Disclosure of social } \\
\text { information }\end{array}$ \\
\hline \multicolumn{3}{|c|}{ R. Associations Between Company Characteristics and IPO Characteristics } \\
\hline Age & {$[-]^{319}$} & $\begin{array}{l}\text { Initial return, defined as market } \\
\text { capitalization at close of listing } \\
\text { date less IPO proceeds }\end{array}$ \\
\hline \multicolumn{3}{|c|}{ S. Associations Between Company Characteristics and Company Survival } \\
\hline Age & {$[-]^{320}$} & $\begin{array}{l}\text { Good delisting, defined as } \\
\text { merger or acquisition }\end{array}$ \\
\hline Age & +++321 & Survival time \\
\hline $\begin{array}{l}\text { Board quality, defined as } \\
\text { percent of nonexecutive } \\
\text { directors }\end{array}$ & {$[-]^{322}$} & $\begin{array}{l}\text { Market switching from Main } \\
\text { Market to AIM }\end{array}$ \\
\hline Board quality, defined as size & {$[-]^{323}$} & $\begin{array}{l}\text { Market switching from Main } \\
\text { Market to AIM }\end{array}$ \\
\hline $\begin{array}{l}\text { UK domicile instead of non- } \\
\text { UK }\end{array}$ & +++324 & Survival time \\
\hline
\end{tabular}

${ }^{314} \mathrm{Id}$. at $527 \mathrm{tbl} .7$.

${ }^{315} \mathrm{Id}$. at 527 tbl.6; MALLIN \& OW-YoNG, supra note 41, at 89 tbl.5.5.

${ }^{316}$ Mallin \& Ow-Yong, supra note 45, at 527 tbl.6.

${ }^{317} \mathrm{Id}$. at 527 tbl.7; MALLIN \& OW-YoNG, supra note 41, at 90 tbl.5.6.

318 Parsa \& Kouhy, supra note 47, at 356 tbl.IX.

${ }^{319}$ Espenlaub et al., supra note 28, at 38 app. tbl.1.

${ }^{320} \mathrm{Id}$. at 29 tbl.8.

${ }^{321}$ Id. at 30 tbl. 9 \& 31 tbl. 10.

${ }^{322}$ Mallin \& Ow-Yong, supra note 45, at 527 tbl.6.

${ }^{323}$ Id.; MALLIN \& OW-YONG, supra note 41, at 89 tbl.5.5.

${ }^{324}$ Espenlaub et al., supra note 28 , at 30 tbl.9 \& 31 tbl. 10. 


\begin{tabular}{|c|c|c|}
\hline \multicolumn{3}{|c|}{ T. Associations Between Company Industry and Company Characteristics } \\
\hline Financial Services & {$[-]^{325}$} & Assets \\
\hline Financial Services & {$[-]^{326}$} & $\begin{array}{l}\text { Board quality, defined as } \\
\text { percent of directors holding } \\
\text { shares }\end{array}$ \\
\hline Financial Services & {$[-]^{327}$} & Board quality, defined as size \\
\hline Manufacturing & $--^{328}$ & Assets \\
\hline Manufacturing & {$[-]^{329}$} & $\begin{array}{l}\text { Board quality, defined as } \\
\text { percent of directors holding } \\
\text { shares }\end{array}$ \\
\hline Manufacturing & {$[+]^{330}$} & Board quality, defined as size \\
\hline Manufacturing & {$[+]^{331}$} & $\begin{array}{l}\text { Disclosure of corporate } \\
\text { governance standards } \\
\text { compliance }\end{array}$ \\
\hline Nonfinancial Services & {$[+]^{332}$} & Assets \\
\hline Nonfinancial Services & +++333 & $\begin{array}{l}\text { Board quality, defined as } \\
\text { percent of directors holding } \\
\text { shares }\end{array}$ \\
\hline Nonfinancial Services & {$[-]^{334}$} & Board quality, defined as size \\
\hline Nonfinancial Services & {$[+]^{335}$} & $\begin{array}{l}\text { Disclosure of corporate } \\
\text { governance standards } \\
\text { compliance }\end{array}$ \\
\hline Resources & {$[+]^{336}$} & Assets \\
\hline Resources & $\ldots-.337$ & $\begin{array}{l}\text { Board quality, defined as } \\
\text { percent of directors holding } \\
\text { shares }\end{array}$ \\
\hline Resources & {$[+]^{338}$} & Board quality, defined as size \\
\hline
\end{tabular}

${ }^{325}$ Mallin \& Ow-Yong, supra note 44, at 30 tbl.6.

$$
\begin{aligned}
& { }^{326} \mathrm{Id} \text {. } \\
& { }^{327} \mathrm{Id} \text {. } \\
& { }^{328} \mathrm{Id} \text {. } \\
& { }^{329} \mathrm{Id} \text {. } \\
& { }^{330} \mathrm{Id} \text {. } \\
& { }^{331} \mathrm{Id} \text {. at } 31 \text { tbl.7. } \\
& { }^{332} \mathrm{Id} \text {. at } 30 \mathrm{tbl} .6 . \\
& { }^{333} \mathrm{Id} \text {. } \\
& { }^{334} \mathrm{Id} \text {. } \\
& { }^{335} \mathrm{Id} \text {. at } 31 \text { tbl.7. } \\
& { }^{336} \mathrm{Id} \text {. at } 30 \mathrm{tbl} .6 . \\
& { }^{337} \mathrm{Id} \text {. }
\end{aligned}
$$




\begin{tabular}{|c|c|c|}
\hline Resources & {$[+]^{339}$} & $\begin{array}{l}\text { Disclosure of corporate } \\
\text { governance standards } \\
\text { compliance }\end{array}$ \\
\hline \multicolumn{3}{|c|}{ U. Associations Between Company Industry and Company Survival } \\
\hline Cyclical Services & {$[-]^{340}$} & $\begin{array}{l}\text { Good delisting, defined as } \\
\text { merger or acquisition }\end{array}$ \\
\hline Cyclical Services & +++341 & Survival time $\quad \cdot \cdots$ \\
\hline Financial Services & {$[-]^{342}$} & $\begin{array}{l}\text { Market switching from Main } \\
\text { Market to AIM }\end{array}$ \\
\hline Financials & -343 & $\begin{array}{l}\text { Good delisting, defined as } \\
\text { merger or acquisition }\end{array}$ \\
\hline Financials & ++344 & Survival time \\
\hline Manufacturing & {$[+]^{345}$} & $\begin{array}{l}\text { Market switching from Main } \\
\text { Market to AIM }\end{array}$ \\
\hline Nonfinancial Services & {$[+]^{346}$} & $\begin{array}{l}\text { Market switching from Main } \\
\text { Market to AIM }\end{array}$ \\
\hline Resources & -347 & $\begin{array}{l}\text { Good delisting, defined as } \\
\text { merger or acquisition }\end{array}$ \\
\hline Resources & $--^{348}$ & $\begin{array}{l}\text { Market switching from Main } \\
\text { Market to AIM }\end{array}$ \\
\hline Resources & $++++^{349}$ & Survival time \\
\hline \multicolumn{3}{|c|}{ V. Associations Between IPO Characteristics and Book Performance } \\
\hline 0 to 1 Years Post-IPO & -350 & Asset Turnover \\
\hline 0 to 1 Years Post-IPO & {$[+]^{351}$} & $\begin{array}{l}\text { Capital Expenditures Over } \\
\text { Total Assets }\end{array}$ \\
\hline
\end{tabular}

${ }^{338} \mathrm{Id}$.

${ }^{339} \mathrm{Id}$. at 31 tbl.7.

${ }^{340}$ Espenlaub et al., supra note 28, at 29 tbl.8.

${ }^{341}$ Id. at 30 tbl.9 \& 31 tbl. 10.

${ }^{342}$ Mallin \& Ow-Yong, supra note 44, at 30 tbl.6.

${ }^{343}$ Espenlaub et al., supra note 28, at 29 tbl.8.

344 Id. at 30 tbl. 9 \& 31 tbl. 10.

${ }^{345}$ Mallin \& Ow-Yong, supra note 44, at 30 tbl.6.

${ }^{346} \mathrm{Id}$.

${ }^{347}$ Espenlaub et al., supra note 28, at 29 tbl.8.

${ }^{348}$ Mallin \& Ow-Yong, supra note 44, at 30 tbl.6.

${ }^{349}$ Espenlaub et al., supra note 28 , at 30 tbl. 9 \& 31 tbl. 10 .

${ }^{350}$ Khurshed et al., supra note 38 , at 28 tbl.5.

${ }^{351}$ Id. at 29 tbl.6. 


\begin{tabular}{|c|c|c|}
\hline 0 to 1 Years Post-IPO & {$[-]^{352}$} & Leverage \\
\hline 0 to 3 Years Post-IPO & {$[+]^{353}$} & Cash Flow Return on Assets \\
\hline 0 to 3 Years Post-IPO & +354 & Return on Assets \\
\hline 0 to 3 Years Post-IPO & {$[+]^{355}$} & Return on Equity \\
\hline 0 to 3 Years Post-IPO & {$[+]^{356}$} & Return on Sales \\
\hline 2 to 3 Years Post-IPO & {$[+]^{357}$} & Asset Turnover \\
\hline 2 to 3 Years Post-IPO & +358 & Leverage \\
\hline \multicolumn{3}{|c|}{ W. Associations Between IPO Characteristics and Market Performance } \\
\hline $\begin{array}{l}\text { Raising capital instead of } \\
\text { listing only }\end{array}$ &.--359 & $\begin{array}{l}\text { Twelve-month buy-and-hold } \\
\text { returns }\end{array}$ \\
\hline $\begin{array}{l}\text { Raising capital instead of } \\
\text { listing only }\end{array}$ & $--^{360}$ & $\begin{array}{l}\text { Eighteen-month buy-and-hold } \\
\text { returns }\end{array}$ \\
\hline $\begin{array}{l}\text { Raising capital instead of } \\
\text { listing only }\end{array}$ & --.361 & $\begin{array}{l}\text { Twenty-four-month buy-and- } \\
\text { hold returns }\end{array}$ \\
\hline \multicolumn{3}{|c|}{ X. Associations Between IPO Characteristics and Company Survival } \\
\hline IPO Initial Return & {$[+]^{362}$} & Survival time \\
\hline \multicolumn{3}{|c|}{ Y. Associations Between Market Switching and Company Characteristics } \\
\hline $\begin{array}{l}\text { Market switching from the } \\
\text { AIM to the Main Market }\end{array}$ & +363 & $\begin{array}{l}\text { Board quality, defined as } \\
\text { nonexecutive Board Chairman } \\
\text { from three years before to three } \\
\text { years after IPO }\end{array}$ \\
\hline
\end{tabular}

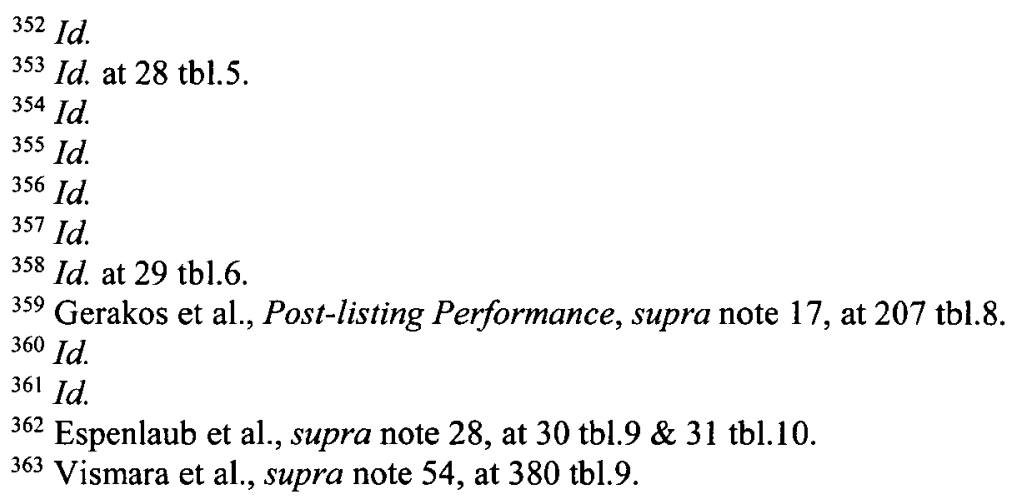




\begin{tabular}{|c|c|c|}
\hline $\begin{array}{l}\text { Market switching from the } \\
\text { AIM to the Main Market }\end{array}$ & $+t^{364}$ & $\begin{array}{l}\text { Board quality, defined as } \\
\text { percent of nonexecutive } \\
\text { directors from three years } \\
\text { before to three years after IPO }\end{array}$ \\
\hline $\begin{array}{l}\text { Market switching from the } \\
\text { AIM to the Main Market }\end{array}$ & +++365 & $\begin{array}{l}\text { Board quality, defined as size } \\
\text { from three years before to three } \\
\text { years after IPO }\end{array}$ \\
\hline $\begin{array}{l}\text { Market switching from the } \\
\text { AIM to the Main Market }\end{array}$ & {$[+]^{366}$} & $\begin{array}{l}\text { Board quality, defined as split } \\
\text { CEO and Board Chairman } \\
\text { positions from three years } \\
\text { before to three years after IPO }\end{array}$ \\
\hline $\begin{array}{l}\text { Market switching from the } \\
\text { Main Market to the AIM }\end{array}$ & {$[+]^{367}$} & Assets \\
\hline $\begin{array}{l}\text { Market switching from the } \\
\text { Main Market to the AIM }\end{array}$ & {$[-]^{368}$} & $\begin{array}{l}\text { Board quality, defined as } \\
\text { nonexecutive Board Chairman } \\
\text { from three years before to three } \\
\text { years after market switch }\end{array}$ \\
\hline $\begin{array}{l}\text { Market switching from the } \\
\text { Main Market to the AIM }\end{array}$ & {$[+]^{369}$} & $\begin{array}{l}\text { Board quality, defined as } \\
\text { percent of directors holding } \\
\text { shares }\end{array}$ \\
\hline $\begin{array}{l}\text { Market switching from the } \\
\text { Main Market to the AIM }\end{array}$ & {$[-]^{370}$} & $\begin{array}{l}\text { Board quality, defined as } \\
\text { percent of nonexecutive } \\
\text { directors }\end{array}$ \\
\hline $\begin{array}{l}\text { Market switching from the } \\
\text { Main Market to the AIM }\end{array}$ & {$[+]^{371}$} & $\begin{array}{l}\text { Board quality, defined as } \\
\text { percent of nonexecutive } \\
\text { directors from three years } \\
\text { before to three years after } \\
\text { market switch }\end{array}$ \\
\hline $\begin{array}{l}\text { Market switching from the } \\
\text { Main Market to the AIM }\end{array}$ & {$[-]^{372}$} & Board quality, defined as size \\
\hline $\begin{array}{l}\text { Market switching from the } \\
\text { Main Market to the AIM }\end{array}$ & {$[+]^{373}$} & $\begin{array}{l}\text { Board quality, defined as size } \\
\text { from three years before to three } \\
\text { years after market switch }\end{array}$ \\
\hline
\end{tabular}

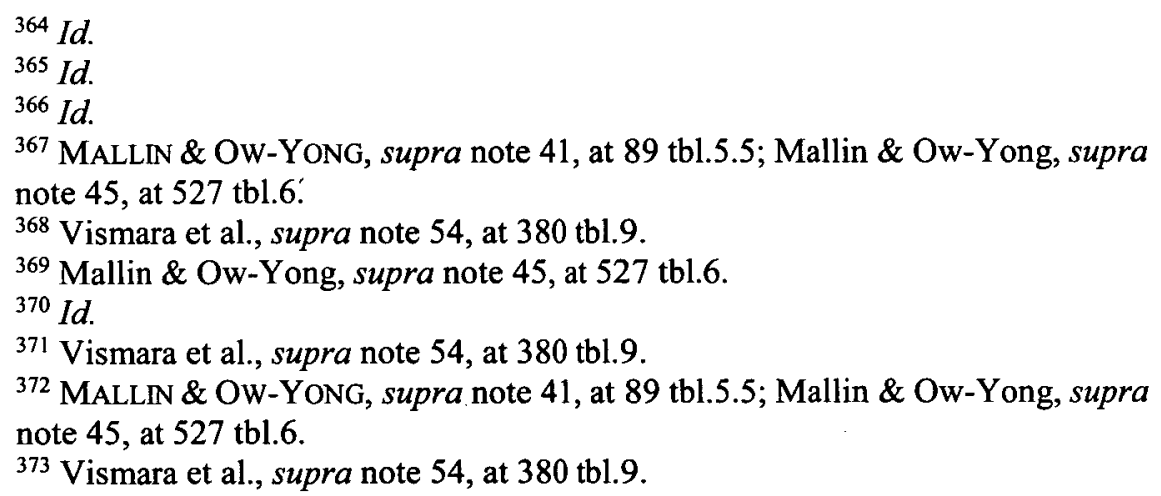




\begin{tabular}{|c|c|c|}
\hline $\begin{array}{l}\text { Market switching from the } \\
\text { Main Market to the AIM }\end{array}$ & -374 & $\begin{array}{l}\text { Board quality, defined as split } \\
\text { CEO and Board Chairman } \\
\text { positions from three years } \\
\text { before to three years after } \\
\text { market switch }\end{array}$ \\
\hline $\begin{array}{l}\text { Market switching from the } \\
\text { Main Market to the AIM }\end{array}$ & $+++^{375}$ & $\begin{array}{l}\text { Disclosure of corporate } \\
\text { governance standards } \\
\text { compliance }\end{array}$ \\
\hline \multicolumn{3}{|c|}{ Z. Associations Between Nomad Characteristics and Company Characteristics } \\
\hline $\begin{array}{l}\text { Nomad quality, defined as the } \\
\text { Nomad is the broker }\end{array}$ & {$[+]^{376}$} & Assets \\
\hline $\begin{array}{l}\text { Nomad quality, defined as the } \\
\text { Nomad is the broker }\end{array}$ & {$[-]^{377}$} & $\begin{array}{l}\text { Board quality, defined as } \\
\text { percent of directors holding } \\
\text { shares }\end{array}$ \\
\hline $\begin{array}{l}\text { Nomad quality, defined as the } \\
\text { Nomad is the broker }\end{array}$ & {$[+]^{378}$} & $\begin{array}{l}\text { Board quality, defined as } \\
\text { percent of nonexecutive } \\
\text { directors }\end{array}$ \\
\hline $\begin{array}{l}\text { Nomad quality, defined as the } \\
\text { Nomad is the broker }\end{array}$ & {$[+]^{379}$} & Board quality, defined as size \\
\hline $\begin{array}{l}\text { Nomad quality, defined as the } \\
\text { Nomad is the broker }\end{array}$ & {$[-]^{380}$} & $\begin{array}{l}\text { Disclosure of corporate } \\
\text { governance standards } \\
\text { compliance }\end{array}$ \\
\hline \multicolumn{3}{|c|}{ AA. Associations Between Nomad Characteristics and Market Liquidity } \\
\hline $\begin{array}{l}\text { Nomad quality, defined as the } \\
\text { natural logarithm of the } \\
\text { number of total delistings of } \\
\text { offerings brought to the AIM } \\
\text { by the Nomad prior the IPO }\end{array}$ & {$[+]^{381}$} & Bid-Ask Spread \\
\hline
\end{tabular}

374 Id.

${ }^{375}$ MALLIN \& OW-YONG, supra note 41, at 90 tbl.5.6; Mallin \& Ow-Yong, supra note 45 , at $527 \mathrm{tbl} .7$.

376 MALLIN \& OW-YONG, supra note 41, at 89 tbl.5.5; Mallin \& Ow-Yong, supra note 45 , at 527 tbl.6.

${ }^{377}$ Mallin \& Ow-Yong, supra note 45, at 527 tbl.6.

378 Id.

${ }^{379}$ MALLIN \& OW-YONG, supra note 41, at 89 tbl.5.5; Mallin \& Ow-Yong, supra note 45 , at 527 tbl.6.

${ }^{380}$ MALLIN \& OW-YONG, supra note 41, at 90 tbl.5.6; Mallin \& Ow-Yong, supra note 45 , at $527 \mathrm{tbl} .7$.

${ }^{381}$ Gerakos et al., Listing Choices, supra note 34, at 58 tbl.10. 


\begin{tabular}{|l|l|l|}
\hline $\begin{array}{l}\text { Nomad quality, defined as the } \\
\text { natural logarithm of the } \\
\text { number of total delistings of } \\
\text { offerings brought to the AIM } \\
\text { by the Nomad prior the IPO }\end{array}$ & $+++^{382}$ & Trading days with zero returns \\
\hline $\begin{array}{l}\text { Nomad quality, defined as the } \\
\text { natural logarithm of the } \\
\text { number of total public } \\
\text { offerings brought to the AIM } \\
\text { by the Nomad prior the IPO }\end{array}$ & $+++^{383}$ & Bid-Ask Spread \\
\hline $\begin{array}{l}\text { Nomad quality, defined as the } \\
\text { natural logarithm of the } \\
\text { number of total public } \\
\text { offerings brought to the AIM } \\
\text { by the Nomad prior the IPO }\end{array}$ & $+++^{384}$ & Trading days with zero returns \\
\hline
\end{tabular}

BB. Associations Between Nomad Characteristics and Market Liquidity

\begin{tabular}{|l|l|l|}
\hline $\begin{array}{l}\text { Nomad quality, defined as the } \\
\text { natural logarithm of the } \\
\text { number of total delistings of } \\
\text { offerings brought to the AIM } \\
\text { by the Nomad prior the IPO }\end{array}$ & {$[+]^{385}$} & Bid-Ask Spread \\
\hline $\begin{array}{l}\text { Nomad quality, defined as the } \\
\text { natural logarithm of the } \\
\text { number of total delistings of } \\
\text { offerings brought to the AIM } \\
\text { by the Nomad prior the IPO }\end{array}$ & +++386 & Trading days with zero returns \\
\hline $\begin{array}{l}\text { Nomad quality, defined as the } \\
\text { natural logarithm of the } \\
\text { number of total public } \\
\text { offerings brought to the AIM } \\
\text { by the Nomad prior the IPO }\end{array}$ & +++387 & Bid-Ask Spread \\
\hline $\begin{array}{l}\text { Nomad quality, defined as the } \\
\text { natural logarithm of the } \\
\text { number of total public } \\
\text { offerings brought to the AIM } \\
\text { by the Nomad prior the IPO }\end{array}$ & +++388 & Trading days with zero returns \\
\hline
\end{tabular}

${ }^{382} \mathrm{Id}$.
${ }^{383} \mathrm{Id}$.
${ }^{384} \mathrm{Id}$.
${ }^{385} \mathrm{Id}$.
${ }^{386} \mathrm{Id}$.
${ }^{387} \mathrm{Id}$
${ }^{388} \mathrm{Id}$.




\begin{tabular}{|c|c|c|}
\hline $\begin{array}{l}\text { Nomad quality, defined as the } \\
\text { natural logarithm of the total } \\
\text { capital raised by the Nomad } \\
\text { prior the IPO }\end{array}$ & {$[-]^{389}$} & Bid-Ask Spread \\
\hline $\begin{array}{l}\text { Nomad quality, defined as the } \\
\text { natural logarithm of the total } \\
\text { capital raised by the Nomad } \\
\text { prior the IPO }\end{array}$ & +++390 & Trading days with zero returns \\
\hline $\begin{array}{l}\text { Nomad quality, defined as the } \\
\text { Nomad is an auditor }\end{array}$ & {$[+]^{391}$} & Bid-Ask Spread \\
\hline $\begin{array}{l}\text { Nomad quality, defined as the } \\
\text { Nomad is an auditor }\end{array}$ & {$[-]^{392}$} & Trading days with zero returns \\
\hline $\begin{array}{l}\text { Nomad quality, defined as the } \\
\text { Nomad is the broker }\end{array}$ & $--^{393}$ & Bid-Ask Spread \\
\hline $\begin{array}{l}\text { Nomad quality, defined as the } \\
\text { Nomad is the broker }\end{array}$ & {$[+]^{394}$} & Trading days with zero returns \\
\hline \multicolumn{3}{|c|}{ CC. Associations Between Nomad Characteristics and Market Performance } \\
\hline $\begin{array}{l}\text { Nomad quality, defined as the } \\
\text { average twelve-month return } \\
\text { for all of the firms brought to } \\
\text { market by a particular Nomad } \\
\text { prior to the current listing. }\end{array}$ & +++395 & $\begin{array}{l}\text { Eighteen-month buy-and-hold } \\
\text { returns }\end{array}$ \\
\hline $\begin{array}{l}\text { Nomad quality, defined as the } \\
\text { natural logarithm of the } \\
\text { number of delistings of } \\
\text { offerings brought to the AIM } \\
\text { by the Nomad prior the firm's } \\
\text { listing }\end{array}$ & {$[+]^{396}$} & $\begin{array}{l}\text { Eighteen-month buy-and-hold } \\
\text { returns }\end{array}$ \\
\hline $\begin{array}{l}\text { Nomad quality, defined as the } \\
\text { natural logarithm of the } \\
\text { number of total public } \\
\text { offerings by the Nomad prior } \\
\text { the firm's listing }\end{array}$ & {$[+]^{397}$} & $\begin{array}{l}\text { Eighteen-month buy-and-hold } \\
\text { returns }\end{array}$ \\
\hline
\end{tabular}

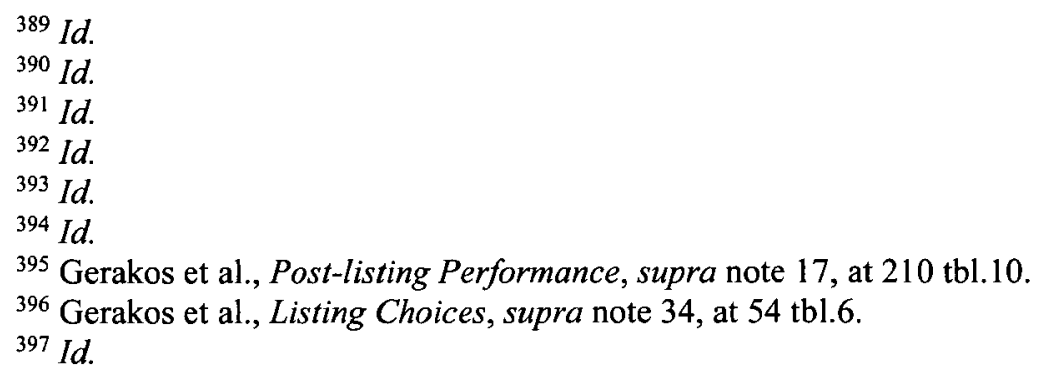




\begin{tabular}{|c|c|c|}
\hline $\begin{array}{l}\text { Nomad quality, defined as the } \\
\text { natural logarithm of the total } \\
\text { capital raised by the Nomad } \\
\text { prior the firm's listing }\end{array}$ & {$[+]^{398}$} & $\begin{array}{l}\text { Eighteen-month buy-and-hold } \\
\text { returns }\end{array}$ \\
\hline $\begin{array}{l}\text { Nomad quality, defined as the } \\
\text { Nomad is an auditor }\end{array}$ & {$[+]^{399}$} & $\begin{array}{l}\text { Eighteen-month buy-and-hold } \\
\text { returns }\end{array}$ \\
\hline $\begin{array}{l}\text { Nomad quality, defined as the } \\
\text { Nomad is the broker }\end{array}$ & {$[+]^{400}$} & $\begin{array}{l}\text { Eighteen-month buy-and-hold } \\
\text { returns }\end{array}$ \\
\hline \multicolumn{3}{|c|}{ DD. Associations Between Nomad Characteristics and Company Survival } \\
\hline $\begin{array}{l}\text { Nomad quality, defined as the } \\
\text { Nomad is the broker }\end{array}$ & {$[-]^{401}$} & $\begin{array}{l}\text { Market switching from Main } \\
\text { Market to AIM }\end{array}$ \\
\hline \multicolumn{3}{|c|}{ EE. Associations Between Ownership and Book Performance } \\
\hline Venture capitalist backing & {$[+]^{402}$} & Sales Growth \\
\hline \multicolumn{3}{|c|}{ FF. Associations Between Ownership and Company Characteristics } \\
\hline $\begin{array}{l}\text { Institutional ownership } \\
\text { percentage }\end{array}$ & $++^{403}$ & Assets \\
\hline $\begin{array}{l}\text { Institutional ownership } \\
\text { percentage }\end{array}$ & -.404 & $\begin{array}{l}\text { Board quality, defined as } \\
\text { percent of directors holding } \\
\text { shares }\end{array}$ \\
\hline $\begin{array}{l}\text { Institutional ownership } \\
\text { percentage }\end{array}$ & {$[+]^{405}$} & $\begin{array}{l}\text { Board quality, defined as } \\
\text { percent of nonexecutive } \\
\text { directors }\end{array}$ \\
\hline $\begin{array}{l}\text { Institutional ownership } \\
\text { percentage }\end{array}$ & {$[+]^{406}$} & Board quality, defined as size \\
\hline
\end{tabular}

$398 \mathrm{Id}$.

399 Id.

${ }^{400}$ Gerakos et al., Post-listing Performance, supra note 17, at 210 tbl. 10.

${ }^{401}$ MALLIN \& OW-YONG, supra note 41, at 89 tbl.5.5; Mallin \& Ow-Yong, supra note 45 , at 527 tbl.6.

402 Colombelli, supra note 26, at 21 tbl.3 \& 22 tbl.4.

${ }^{403}$ MALLIN \& OW-YONG, supra note 41, at 89 tbl.5.5; Mallin \& Ow-Yong, supra note 45 , at 527 tbl. 6 .

404 Mallin \& Ow-Yong, supra note 45, at 527 tbl.6.

$405 \mathrm{Id}$.

${ }^{406}$ Id.; MALLIN \& OW-YONG, supra note 41, at 89 tbl.5.5. 


\begin{tabular}{|c|c|c|}
\hline $\begin{array}{l}\text { Institutional ownership } \\
\text { percentage }\end{array}$ & {$[+]^{407}$} & $\begin{array}{l}\text { Disclosure of corporate } \\
\text { governance standards } \\
\text { compliance }\end{array}$ \\
\hline Managerial ownership percent & $\ldots .-408$ & Assets \\
\hline Managerial ownership percent & $--^{409}$ & $\begin{array}{l}\text { Board quality, defined as } \\
\text { percent of nonexecutive } \\
\text { directors }\end{array}$ \\
\hline Managerial ownership percent & {$[+]^{410}$} & Board quality, defined as size \\
\hline Managerial ownership percent & {$[-]^{411}$} & $\begin{array}{l}\text { Disclosure of corporate } \\
\text { governance standards } \\
\text { compliance }\end{array}$ \\
\hline \multicolumn{3}{|c|}{ GG. Associations Between Ownership and Market Performance } \\
\hline $\begin{array}{l}\text { Retail investor ownership } \\
\text { percentage }\end{array}$ & $--^{412}$ & $\begin{array}{l}\text { Twelve-month buy-and-hold } \\
\text { returns }\end{array}$ \\
\hline $\begin{array}{l}\text { Retail investor ownership } \\
\text { percentage }\end{array}$ & -413 & $\begin{array}{l}\text { Eighteen-month buy-and-hold } \\
\text { returns }\end{array}$ \\
\hline $\begin{array}{l}\text { Retail investor ownership } \\
\text { percentage }\end{array}$ & -414 & $\begin{array}{l}\text { Twenty-four-month buy-and- } \\
\text { hold returns }\end{array}$ \\
\hline \multicolumn{3}{|c|}{ HH. Associations Between Ownership and Company Survival } \\
\hline $\begin{array}{l}\text { Institutional ownership } \\
\text { percentage }\end{array}$ & {$[-]^{415}$} & $\begin{array}{l}\text { Market switching from Main } \\
\text { Market to AIM }\end{array}$ \\
\hline Managerial ownership percent & {$[+]^{416}$} & $\begin{array}{l}\text { Market switching from Main } \\
\text { Market to AIM }\end{array}$ \\
\hline Venture capitalist backing & {$[+]^{417}$} & Delisting \\
\hline Venture capitalist backing & {$[+]^{418}$} & Survival time \\
\hline
\end{tabular}

${ }^{407}$ MALLIN \& OW-YONG, supra note 41, at 90 tbl.5.6; Mallin \& Ow-Yong, supra note 45 , at 527 tbl. 7 .

${ }^{408}$ Mallin \& Ow-Yong, supra note 45, at 527 tbl.6.

${ }^{409} \mathrm{Id}$.

${ }^{410} \mathrm{Id}$.

${ }^{411} I d$. at 527 tbl. 7 .

${ }^{412}$ Gerakos et al., Post-listing Performance, supra note 17, at 211 tbl.11.

${ }^{413} \mathrm{Id}$.

414 Id.

${ }^{415}$ MALLIN \& OW-YoNG, supra note 41, at 89 tbl.5.5; Mallin \& Ow-Yong, supra note 45 , at 527 tbl.6.

${ }^{416}$ Mallin \& Ow-Yong, supra note 45, at 527 tbl.6.

${ }^{417}$ Espenlaub et al., supra note 28 , at 30 tbl.9 \& 31 tbl. 10 .

${ }^{418} I d$. 
